\title{
CORRECTING FEDERALISM MISTAKES IN STATUTORY INTERPRETATION: THE SUPREME COURT AND THE FEDERAL ARBITRATION ACT
}

\author{
DAVID S. SCHWARTZ*
}

\section{INTRODUCTION}

Can the U.S. Supreme Court correct a major federalism mistake of its own creation? Should it? The current judicial treatment of the Federal Arbitration $\operatorname{Act}^{1}$ (FAA) is an embarrassment to a Court whose majority is supposed to be leading a federalism revival, if not a federalism revolution. ${ }^{2}$ In 1984, in Southland Corp. v. Keating, ${ }^{3}$ the Court held that the FAA is substantive federal law that preempts state laws regulating arbitration agreements. The Court thereby transformed a quaint, sixty-year-old procedural statute into "a permanent, unauthorized eviction of state-court power to adjudicate a potentially large class of disputes, ${ }^{\prime 4}$ as well as an eviction of state lawmaking power over the traditional state domain of contract law. Even worse, Southland preempts this area of traditional state regulation without the justification of any strong federal interest. Despite its constant, talismanic repetition, the "national policy favoring arbitration" is illusory and is highly dubious federalism. What significant federal interest is at stake in a state's policy choice between opening its courts to litigants or compelling them to arbitrate pursuant to private contracts?

\section{Copyright $(9) 2004$ by David S. Schwartz}

This Article is also available at http://www.law.duke.edu/journals/67LCPSchwartz.

* Assistant Professor of Law, University of Wisconsin Law School.

I am very grateful to my colleagues who reviewed and commented on drafts of this Article: Ann Althouse, Sarah Cole, Neil Komesar, Thomas Metzloff, Jane Schacter, and the participants of the Roscoe Pound Institute/Duke University School of Law Symposium, "The Coming Crisis in Mandatory Arbitration." I am particularly indebted to Thomas Metzloff and Richard Marshall for inviting me to participate in the symposium. Finally, I gratefully acknowledge the valuable research assistance provided by Carlos Becerra, Angela Olson, and Celenda Wagenknecht.

1. 9 U.S.C. $\S \S 1-16(2000)$.

2. See Richard H. Fallon, The "Conservative" Paths of the Rehnquist Court's Federalism Decisions, 69 U. CHI. L. REV. 429, 430 (2002) ("Commentators unhesitatingly refer to a federalism 'revival.' Law reviews echo with discussion of whether the Court has yet achieved, or is likely to effect, a federalism 'revolution."'); see also Erwin Chemerinsky, The Federalism Revolution, 31 N.M. L. REV. 7 (2001).

3. 465 U.S. 1 (1984).

4. Allied-Bruce Terminix Cos. v. Dobson, 513 U.S. 265, 285 (1995) (Scalia, J., dissenting).

5. Southland, 465 U.S. at 10. 
Southland is anomalous in several respects. It creates the only federal cause of action that gives rise to no federal-question jurisdiction and affects no substantive rights. And while the Rehnquist "federalism-revival" Court has reaffirmed and extended Southland's intrusion on state lawmaking autonomy, it may be that no Justice on that Court believes Southland was correctly decided: no member of the Southland majority remained on the Court as of 1994, and five current members of the Court have at one time or another dissented from Southland or a case applying it. With four federalist Justices on record against it, a fifth who by rights should be, and at least one against it from the "liberal" wing of the Court, why does Southland remain? Justice Stevens has suggested that, while contrary to congressional intent, the Southland preemption rule is supported, at least up to a point, by "intervening developments" in the law since 1925 . $^{6}$ Justice O'Connor, while continuing to believe that Southland is wrong, nevertheless has "acquiesced" in reaffirming it in deference to the "special force" of stare decisis in statutory interpretation cases." And finally, at least some Justices-perhaps a majority-find the decision justified in retrospect by the "national policy favoring arbitration" that Southland largely created. ${ }^{8}$

But Southland is wrong, and the justifications for it are wrong. Part II of this Article outlines the Southland decision and shows how its preemption rule comes at a very high cost to the federalism values espoused by the Court in its recent federalism jurisprudence. Part III argues that Southland was wrong from the outset as a matter of black-letter preemption doctrine. Because preemption is a matter of congressional intent, the Court should have been guided by the persuasive historical record that Congress never intended the FAA to preempt state law. The historical case against FAA preemption is even stronger than has been articulated in past dissenting opinions or scholarly accounts.

Parts IV through VI consider the alternative justifications for adhering to Southland and argue that none is adequate. Part IV considers whether Southland's acknowledged departure from congressional intent nevertheless can be accepted as "dynamic" statutory interpretation-that is, the theory that statutes may be broadly or loosely construed to serve pressing policy concerns not anticipated by the original drafters. ${ }^{9}$ Neither of the two public policy concerns argued in Southland itself - the prevention of forum shopping and "the national policy favoring arbitration"-justify the undermining of federalism values implicit in broad federal preemption. Both policies are illusory in light of the Court's established view that arbitration agreements are simply a specialized type of forum-selection clause having no impact on substantive outcomes. From a federalism perspective, it is constitutionally problematic, if not plainly unconstitutional, for Congress (or "Congress" as a cat's paw for the Supreme

6. 465 U.S. at 17 (Stevens, J., concurring in part and dissenting in part).

7. Allied-Bruce, 513 U.S. at 283-84 (O'Connor, J., concurring).

8. 465 U.S. at 10.

9. See William N. ESKRidge, Dynamic Statutory Interpretation 13 (1994). 
Court) to dictate to states when they may make their courts available to litigants in cases that do not implicate federal jurisdiction.

Part V addresses an alternative argument for dynamic interpretation of the FAA: Justice Stevens's suggestion that intervening legal history since 1925 supports the judicial reconstruction of the FAA culminating in Southland. Part V argues that Southland's interpretation of the FAA as preemptive substantive law is the result of two major federalism errors: a sequence of missteps and non sequiturs seeking to resolve an illusory "Erie ${ }^{10}$ problem," combined with a false analogy between the FAA and the judicial nationalism of federal labor law.

Part VI argues that Justice O'Connor was wrong and that Justice Scalia was right - that "proper application of stare decisis does not prevent correction of the mistake" of Southland. ${ }^{11}$ Whatever might be said for the interest in adhering to stare decisis in statutory interpretation cases, special considerations justify departure when a mistaken interpretation raises significant constitutional questions of federalism. By authorizing the creation of a "body of federal substantive [common] law," Southland's misinterpretation of the FAA is much like the constitutional error of Swift v. Tyson, ${ }^{12}$ whose interpretation of section 34 of the Judiciary Act of $1789^{13}$ was famously overruled by Erie. ${ }^{14}$ Indeed, in an important respect, Southland is a worse mistake than Swift: the federal common law created under the Swift regime did not apply in state court; that created under Southland does. Moreover, it is a contradiction for the Court to maintain that Congress must act to correct the Court's federalism mistake when, elsewhere, the Court has argued that federalism principles require it to correct the mistakes of Congress.

Finally, Part VII offers three alternative interpretations of the FAA that could be adopted in overruling Southland.

\section{SOUTHLAND AND THE FEDERALISM REVIVAL}

\section{A. Southland's Reinterpretation of the FAA}

In Southland Corp. v. Keating, several California franchisees of 7-Eleven convenience stores sued Southland, the corporate owner-franchisor of the 7Eleven chain, in state court. The plaintiffs advanced various state-law theories, including claims under a state statute designed to protect franchisees from overreaching. ${ }^{15}$ Southland sought to compel arbitration of all claims pursuant to an

10. Erie R.R. Co. v. Tompkins, 304 U.S. 64 (1938) (deciding how federal courts sitting in diversity are to determine whether state or federal legal standards govern).

11. Allied-Bruce, 513 U.S. at 284 (Scalia, J., dissenting).

12. 42 U.S. (16 Pet.) 1 (1842).

13. 1 Stat. $73(1790)$.

14. 304 U.S. 64 (1938).

15. California Franchise Investment Law, CAL. CORP. CODE $\S \S 31000-31516$ (West 1977); see Southland, 465 U.S. at 21 (Stevens, J., dissenting) (explaining the purpose of the law). 
arbitration clause in the standard-form franchise agreement, but the California Supreme Court construed the franchise law to preclude arbitration of the statutory claim. ${ }^{16}$ The U.S. Supreme Court reversed, holding that the state rule against arbitrating statutory franchise disputes was preempted by section 2 of the FAA. "In enacting $§ 2$ of the federal Act," the Court held, "Congress declared a national policy favoring arbitration and withdrew the power of the states to require a judicial forum for the resolution of claims which the contracting parties agreed to resolve by arbitration." 17

The proposition that the FAA preempted any state law that would limit the enforceability of arbitration agreements was brand new. Chief Justice Burger's majority opinion sought to justify this reinvention of the FAA in large part with a pair of policy rationales: a policy against forum shopping and a newly conceived "national policy favoring arbitration." 18 Because preemption is a question of congressional intent, the main focus of the majority's opinion was interpreting the language and history of the FAA. The statute itself is silent with regard to its effect on state law. Straining to draw favorable inferences from a legislative history it determined to be "not without ambiguities," and ignoring clear indications that the FAA was not intended to bind the states, the Southland majority reasoned that Congress, by basing the FAA on its power "to enact substantive rules under the Commerce Clause," must have intended to make substantive law, binding on state as well as federal courts. ${ }^{19}$

If original congressional intent is the touchstone of a statute's preemptive effect, Southland was plainly wrong. The historical record clearly shows that the FAA was intended to be a procedural statute for the federal courts, that it was not intended to preempt state law, and that it was designed to reverse the "ouster doctrine" ${ }^{20}$ but otherwise preserve all applicable state contract law. Ignoring all this, the Southland majority asserted it was "inexplicable" that Congress would have limited the FAA's scope to contracts in interstate commerce and admiralty if it had intended only to make procedural law for the federal courts: "We therefore view the 'involving commerce' requirement in $\S 2$, not as an inexplicable limitation on the power of the federal courts, but as a necessary qualification on a statute intended to apply in state and federal courts." ${ }^{21}$ As will be seen, the "involving commerce" requirement was the very explicable result of a Senate amendment designed to narrow the FAA's reach. ${ }^{22}$

Nor was there anything unprecedented in either using the commerce power to enact a procedural rule or creating a procedural rule applicable to a limited

16. See Southland, 465 U.S. at 10 (citing CAL. CoRP. CODE $\S 31512$ (West 1977)).

17. Id.

18. Id. at $10-14$.

19. Id. at $11-12$.

20. See infra text accompanying notes 74-79.

21. 465 U.S. at $14-15$.

22. See infra Part III.B.2. 
subset of federal judicial business. ${ }^{23}$ As Justice Thomas would later put it, "Congress might well have thought that even if it could have called upon federal courts to enforce arbitration agreements in every single case that came before them, there was no federal interest in doing so unless interstate commerce or maritime transactions were involved." ${ }^{24}$

On the other hand, the majority's interpretation of the FAA as preempting state law creates a difficulty that is much harder to explain than a provision limiting a federal procedural rule to cases involving interstate contracts: Why would Congress create a "substantive" federal right without creating federal subject matter jurisdiction for its vindication? The FAA provides for enforcement of section 2 only in federal courts, either when a suit is already pending (section 3), or by petition to a federal district court that "save for such agreement, would have jurisdiction" (section 4 ). ${ }^{25}$ These provisions have always been understood as conferring no independent federal question jurisdiction. ${ }^{26}$ When it suggested for the first time, in the year before Southland, that the FAA created a substantive federal right, the Court began transforming the FAA into "something of an anomaly in the field of federal-court jurisdiction." Southland majority noted this anomaly, but made no attempt to explain why Congress would have created it. ${ }^{28}$

Three Justices dissented. Justice O'Connor, joined by then-Justice Rehnquist, relying on some of the historical evidence detailed above, argued that the FAA was intended to establish purely procedural rules enforceable only in federal court and therefore could not be construed to bind state courts or to preempt state law..$^{29}$ Justice Stevens, although agreeing that the FAA was originally intended to be procedural, felt that "intervening developments" compelled the conclusion that the FAA preempts state law regulating arbitration agreements in general. He argued, however, that the savings clause preserves "certain substantive state policies that would be undermined by enforcing certain categories of arbitration clauses." ${ }^{30}$

Since Southland, the principle of FAA preemption has become firmly established. The Supreme Court itself has reaffirmed or extended Southland in four

23. See 465 U.S. at 26 n.11 (O'Connor, J., dissenting) (citing, among other things, FED. R. CIV. P. 81(a), which provides that the Federal Rules of Civil Procedure are inapplicable to certain admiralty, copyright, and bankruptcy proceedings).

24. Allied-Bruce Terminix Cos. v. Dobson, 513 U.S. 265, 292 (1995) (Thomas, J., dissenting).

25. The phrase "courts of the United States" in section 3 means the federal courts. See infra note 92 and accompanying text.

26. See Moses H. Cone Mem'l Hosp. v. Mercury Constr. Corp., 460 U.S. 1, 25 n.32 (1983). For early cases, see Krauss Bros. Lumber Co. v. Louis Bossert \& Sons, Inc., 62 F.2d 1004, 1006 (2d Cir. 1933); In re Woerner, 31 F.2d 283, 283 (2d Cir. 1929).

27. Moses H. Cone, 460 U.S. at 25 n.32.

28. Southland, 465 U.S. at 15 n.9.

29. Id. at 23 (O'Connor, J., dissenting).

30. Id. at 18 (Stevens, J., concurring in part and dissenting in part). 
cases. ${ }^{31}$ In Allied-Bruce Terminix Cos. v. Dobson, ${ }^{32}$ for example, the Court held that the FAA preempted an Alabama statute making predispute arbitration agreements unenforceable. Although preemption in Allied-Bruce followed from a straightforward application of Southland, the case is significant because a strong argument was made, with the endorsement of twenty state attorneys general as amici curiae, ${ }^{33}$ that Southland should be overruled. In a concurring opinion in Allied-Bruce, Justice O'Connor reluctantly "acquiesce[d] in today's judgment" on the strength of "considerations of stare decisis, which we have said have 'special force in the area of statutory interpretation." ${ }^{34}$ Although Southland was wrong, it would rest with Congress to correct the mistake..$^{35}$

For Justice Scalia, dissenting in Allied-Bruce, "Southland clearly misconstrued the Federal Arbitration Act," and "entails a permanent, unauthorized eviction of state-court power to adjudicate a potentially large class of disputes. ${ }^{36}$ Justice Scalia argued further that Justice O'Connor's scruple about stare decisis was misplaced. Unlike a substantive rule of decision, he argued, an arbitration clause is merely a forum-selection clause that should not affect "[p]rimary behavior" or create substantial reliance interests on "the Southland guarantee" of preemption. Therefore, he did "not believe that proper application of stare decisis prevents correction of the mistake." ${ }^{37}$ Justice Scalia added that although he would no longer dissent from decisions resting on Southland, he would "join four other Justices in overruling it." ${ }^{\text {" Fin }}$ Filly, Justice Thomas, in a dissent joined by Justice Scalia, took up the argument that the FAA is a procedural statute. With Justices Scalia and Thomas joining the original three Southland dissenters, five Justices on the present Court have at one time or another dissented from the Southland preemption principle.

31. See Doctor's Assocs. v. Casarotto, 517 U.S. 681 (1996) (holding that FAA section 2 preempts a Montana statute imposing protective form requirements on arbitration agreements); Allied-Bruce, 513 U.S. at 265 (holding that section 2 preempts an Alabama statute barring enforcement of predispute arbitration agreements); Perry v. Thomas, 482 U.S. 483 (1987) (holding that section 2 preempts a California statute barring enforcement of predispute arbitration agreements for wage-and-hour claims). In Circuit City Stores v. Adams, 532 U.S. 105 (2001), the Court brushed aside an opportunity to employ the federalism-based presumption against preemption, which would have allowed the Court to decline to extend Southland further. See infra text accompanying notes 61-66. In two other cases, the Court has stated that the FAA would preempt state laws that "would undermine the goals and policies of the FAA.” Volt Info. Scis., Inc. v. Bd. of Trs. of Leland Stanford Junior Univ., 489 U.S. 468, $477-78$ (1989); see also Mastrobuono v. Shearson Lehman Hutton, Inc., 514 U.S. 52, 59 (1995) (holding that "in the absence of contractual intent to the contrary, [the] FAA would preempt" state decisional law precluding punitive damage awards by arbitrators).

32. 513 U.S. 265 (1995).

33. Id. at 272.

34. Id. at 283-84 (O'Connor, J., concurring) (quoting Patterson v. McLean Credit Union, 491 U.S. $164,172-73(1989))$.

35. Id . at 284 (O'Connor, J., concurring). Justice Stevens joined the majority, probably because he believed the Alabama law to be a generalized, anti-arbitration statute of the type that he suggested would be preempted in his partial concurrence in Southland.

36. Id. at 284-85 (Scalia, J., dissenting).

37. Id. at 284.

38. Id. at 285. 


\section{B. Southland's Tension with Federalism}

Southland is very much out of step with the Court's federalism decisions of the past decade. Its broad rule of preemption comes at great cost to state lawmaking autonomy, the primary value of federalism.

\section{The Federalism Revival and State Lawmaking Autonomy}

Since 1991, the Supreme Court has, in the name of federalism, struck down provisions of several acts of Congress ${ }^{39}$ and overruled or curtailed several key precedents. ${ }^{40}$ The most ambitious normative justification given for the Court's federalism revival is Justice O'Connor's opinion in Gregory v. Ashcroft ${ }^{41}$ which has been frequently echoed in whole or in part in subsequent federalism cases: ${ }^{42}$

This federalist structure of joint sovereigns preserves to the people numerous advantages. It assures a decentralized government that will be more sensitive to the diverse needs of a heterogeneous society; it increases opportunity for citizen involvement in democratic processes; it allows for more innovation and experimentation in government; and it makes government more responsive by putting the States in competition for a mobile citizenry. ${ }^{43}$

Picking up the themes of "experimentation" and "competition for a mobile citizenry," the concurrence by Justice Kennedy in United States v. Lopez relied heavily on Justice Brandeis's famous dictum that the states can serve as "laboratories for experimentation" in social policy. ${ }^{44}$ A common thread runs through these various values of federalism. All assume a substantial degree of state lawmaking autonomy; none would have much meaning if the states were merely administrative units of a single, national sovereign. Decentralization, diversity, and experimentation all directly require that the states enact and implement their own policies. Even the "republican" virtue of participation in government presupposes that there is a government worth the time and trouble. A govern-

39. E.g., United States v. Morrison, 529 U.S. 598 (2000) (striking down the civil enforcement provision of the Violence Against Women Act); Printz v. United States, 521 U.S. 898 (1997) (striking down provisions of the Brady Act requiring state cooperation in federal gun control); United States v. Lopez, 514 U.S. 549 (1995) (striking down the Gun Free School Zones Act); see also Fallon, supra note 2, at 430 n.2 (citing "at least ten" such instances).

40. E.g., Kimel v. Fla. Bd. of Regents, 528 U.S. 62 (2000) (holding an Age Discrimination in Employment Act (ADEA) provision providing a private right of action against states an invalid abrogation of sovereign immunity), significantly limiting EEOC v. Wyoming, 460 U.S. 226 (1983) (upholding Congress's authority to extend the ADEA to states under the Commerce Clause); Seminole Tribe of Fla. v. Florida, 517 U.S. 44 (1996) (invalidating a provision of the Indian Gaming Regulatory Act abrogating state sovereign immunity pursuant to Article I powers), overruling Pennsylvania v. Union Gas Co., 491 U.S. 1 (1989) (holding Congress can abrogate sovereign immunity pursuant to Article I powers).

41. 501 U.S. 452 (1991).

42. See, e.g., Lopez, 514 U.S. at 552 (citing Gregory as setting forth the "first principles" of federalism).

43. 501 U.S. at 458.

44. "[O]ne of the happy incidents of the federal system [is] that a single courageous State may, if its citizens choose, serve as a laboratory; and try novel social and economic experiments without risk to the rest of the country." New State Ice Co. v. Liebmann, 285 U.S. 262, 311 (1932) (Brandeis, J., dissenting), quoted in Lopez, 514 U.S. at 581 (Kennedy, J., concurring). 
mental sub-unit without lawmaking sovereignty would not likely generate as much interest in its politics as do states in our federal system.

Preemption doctrine-the application of a federal statute to nullify state laws under the Supremacy Clause ${ }^{45}$-represents the most significant and frequently applied limitation on substantive state autonomy in our constitutional scheme. ${ }^{46}$ As a practical matter, Lopez and United States v. Morrison have not significantly curtailed the federal commerce power, which still potentially reaches most subjects of legislation. ${ }^{47}$ But preemption doctrine holds that Congress may nullify state law on any subject within federal legislative jurisdiction. "[T] he true test of federalist principle may lie," therefore, "not in the occasional effort to trim Congress'[s] commerce power at its edges, or to protect a State's treasury from a private damages action, but rather in those many statutory cases where courts interpret the mass of technical detail that is the ordinary diet of the law"-namely, preemption cases. ${ }^{48}$

Recognizing this, the Supreme Court has held that federalism concerns support a "presumption against preemption" according to which the Court will not read ambiguous statutes to displace state laws in areas of traditional state regulation. $^{49}$ In Gregory, the Court took this principle a step farther: "If Congress intends to alter the "usual constitutional balance between the States and the Federal Government,' it must make its intention 'unmistakably clear in the language of the statute." ${ }^{50}$ In essence, Gregory makes federalism values an important canon of statutory interpretation that should weigh strongly against Southland's policy-based interpretation of the FAA as preempting state law. Not surprisingly, contracts are an area of traditional state regulation that federal courts should be "reluctant to federalize."

45. U.S. CONST. art. VI, cl. 2.

46. See, e.g., Stephen A. Gardbaum, The Nature of Preemption, 79 CORNELl L. REV. 767, 768 (1994) (commenting that preemption "is almost certainly the most frequently used doctrine of constitutional law in practice"); David S. Schwartz, Failing the "True Test" of Federalism: Preemption, the Supremacy Clause and the Federalism Revival (unpublished manuscript, on file with author).

47. See generally Ronald D. Rotunda, The Implications of the New Commerce Clause Jurisprudence: An Evolutionary or Revolutionary Court?, 55 ARK. L. REV. 795 (2003).

48. Egelhoff v. Egelhoff, 532 U.S. 141, 160-61 (2001) (Breyer, J., dissenting) (citations omitted).

49. See, e.g., Allied-Bruce Terminix Cos. v. Dobson, 513 U.S. 265, 283 (1995) (O’Connor, J., concurring) ("“[W]here... the field which Congress is said to have preempted includes areas that have been traditionally occupied by the States,' congressional intent to supersede state laws must be 'clear and manifest."') (quoting English v. Gen. Elec. Co., 496 U.S. 72, 78-79 (1990)); Id. at 292 (Thomas, J., dissenting) ("To the extent that federal statutes are ambiguous, we do not read them to displace state law.”); accord Southland Corp. v. Keating, 465 U.S. 1, 18 (1984) (Stevens, J., concurring in part and dissenting in part) ("The exercise of state authority in a field traditionally occupied by state law will not be deemed pre-empted by a federal statute unless that was the clear and manifest purpose of Congress.").

50. Gregory v. Ashcroft, 501 U.S. 452, 460 (1991) (quoting Will v. Mich. Dep't of State Police, 491 U.S. 58, 65 (1989), in turn quoting Atascadero State Hosp. v. Scanlon, 473 U.S. 234, 242 (1985)).

51. Patterson v. McLean Credit Union, 491 U.S. 164, 183 (1989) (quoting Santa Fe Indus. v. Green, 430 U.S. 462,479 (1977)). 


\section{The Impact of FAA Preemption on State Autonomy}

The preemptive effect given to the FAA as a result of Southland provides a prime example of the intrusion on state sovereignty resulting from preemption. It has done considerable violence to the notion of the states as "laboratories for experimentation" by shutting down state experiments in the regulation of arbitration agreements and inhibiting state case law development in this field.

Arbitration agreements are widely regarded as a form of self-help deregulation by corporations subject to various consumer- and employee-protection laws. $^{52}$ Because of this, a number of states have enacted laws attempting to curb potential abuses of arbitration agreements. These almost invariably have been held preempted; the Supreme Court alone has voided four such laws. ${ }^{53}$

The state laws that have been held preempted, or that might be subject to preemption, come in a variety of shapes and sizes. Alabama has the broadest statute, providing simply that a written predispute arbitration agreement is invalid. $^{54}$ Most states have enacted arbitration statutes providing for specific enforcement of arbitration agreements, adopting language similar to the FAA ${ }^{55}$ but several of these statutes carve out exceptions to the general rule of enforcement. ${ }^{56}$ While the Supreme Court has held that Congress may exempt certain kinds of claims from arbitration by an express provision or by implication, ${ }^{57}$ under Southland, states are denied that authority. ${ }^{58}$ Nor can states condition enforcement of arbitration agreements on adherence to special formal requirements, such as printed notice-a common form of consumer-protection

52. See, e.g., David S. Schwartz, Enforcing Small Print to Protect Big Business: Employee and Consumer Rights Claims in an Age of Compelled Arbitration, 1997 WIS. L. REV. 33, 62-66.

53. See supra note 31 .

54. AlA. CODE § 8-1-41(3) (1993), held preempted by Allied-Bruce Terminix Cos. v. Dobson, 513 U.S. 265 (1995).

55. Forty-seven states and the District of Columbia have arbitration-enforcement statutes creating mechanisms similar to the FAA. See 5 IAn R. MACneIl, ET Al., Federal Arbitration Law: AgreEments, AwARds \& REMEdies Under the FEDERAL ARbitration ACT 41-44 app. I (5th ed. 1994).

56. Iowa and Missouri provide that arbitration agreements are unenforceable if they are found in "contracts of adhesion." IOWA CODE ANN. § 679A.1(2)(a) (West 1999), held preempted in Heaberling Farms Inc. v. IGF Ins. Co., 641 N.W.2d 816, 822-23 (Iowa 2002); MO. REV. STAT. § 435.350 (2001), held preempted in Standard Sec. Life Ins. Co. v. West, 127 F. Supp. 2d 1064 (W.D. Mo. 2000). Arkansas, Iowa, Kansas, and South Carolina have provisions of their arbitration statutes exempting tort claims from coverage. ARK. CODE ANN. § 16-108-201(b) (Michie 2001); IOWA CODE ANN. § 679A.1(2)(c); KAN. STAT. ANN. § 5-401(c)(3) (2002); S.C. CODE ANN. § 15-48-10(b)(2) (Law Co-op 2002), held preempted in Munoz v. Green Tree Fin. Corp., 542 S.E.2d 360, 365 (S.C. 2001).

57. Shearson/Am. Express v. McMahon, 482 U.S. 220, 226-27 (1987).

58. Thus, a provision in California's labor code preserving the administrative and judicial forum and barring enforcement of arbitration agreements for claims for unpaid wages was held preempted by the Court in Perry v. Thomas, 482 U.S. 483 (1987) (holding preempted CAL. LAB. CoDE $§ 229$ (West 1971)). 
regulation. ${ }^{59}$ The most widespread form of state law subject to Southland preemption is the regulation of predispute arbitration agreements in employment contracts. At least eleven states would decline to enforce arbitration agreements in employment disputes. ${ }^{60}$

The prevalence of state laws exempting employment disputes from arbitration enforcement gave particular significance to the Supreme Court's 2001 decision in Circuit City Stores v. Adams. ${ }^{61}$ In Circuit City, the Court was required to determine the scope of an exclusion in section 1 of the FAA that exempts from FAA coverage all "contracts of employment of seamen, railroad employees, or any other class of workers engaged in foreign or interstate commerce." ${ }^{22}$ The Court concluded that the canon of statutory construction known as ejusdem generis "compelled" it to construe narrowly section 1's phrase "any other class of workers" to embrace types of workers "similar in nature" to railroad employees and seamen, thus exempting only transportation workers from FAA coverage. $^{63}$

In light of the federalism revival, the Circuit City decision is surprising. There can be no doubt that the section 1 exclusion is ambiguous. The distortion worked on the FAA by the subsequent expansion of the Commerce Clause, the unusual "involving commerce" and "evidencing a transaction" language in section 2's coverage provision, and the sharp disagreement among courts and

59. See Doctor's Assocs. v. Casarotto, 517 U.S. 681, 686-87 (1996) (holding preempted MonT. CODE ANN. §27-5-114(4) (1995), which required that printed notice of an arbitration clause appear on the first page of a form contract, in prominent type).

60. See ARIZ. ReV. StAT. § 12-1517 (2001) (providing that the state's arbitration statute "shall have no application to arbitration agreements between employers and employees"), held preempted in Alphagraphics Franchising, Inc. v. Whaler Graphics, Inc., 840 F. Supp. 708, 711 (D. Ariz. 1993); ARK. CODE ANN. § 16-108-201(b) (Michie 2001) (exempting "employer-employee disputes"); IOWA CODE ANN. § 679A.1(2)(b) (West 2002) (exempting "a contract between employers and employees"); KAN. STAT. ANN. § 5-401(c)(1) (2002) (exempting "contracts between employers and employees"); KY. REV. STAT. ANN. § 336.700(2) (Michie 2002) ("[N]o employer shall require as a condition or precondition of employment that any employee or person seeking employment waive, arbitrate, or otherwise diminish any existing or future claim."); $i d$. at $\S 417.050(2)$ (providing that "arbitration agreements between employers and employees" will not be enforced); MD. CODE ANN., CTS. \& JUD. PROC. 3-206(b) (exempting "an arbitration agreement between employers and employees"); S.C. CODE ANN. § 15-4810(b)(4) (Law Co-op 2002) (precluding arbitration of "workmen's compensation claims, unemployment compensation claims and collective bargaining disputes" and providing that an arbitration agreement "shall not be made a condition of employment"); WIS. STAT. § 788.01 (2002) (exempting contracts of employment), held preempted in Bungard v. Rural Mut. Ins. Co., 537 N.W.2d 433 (Wis. Ct. App. 1995). In addition, Alabama's prohibition on enforcement of predispute arbitration agreements, ALA. CODE $\S$ 8-1-41(3) (1993), and Missouri's on adhesion contracts, MO. REV. STAT. § 435.350 (2001), would also apply to employment cases. California and Colorado bar enforcement of arbitration agreements for wage-and-hour claims. CAL. LAB. CODE $§ 229$ (West 1979), held preempted in Perry v. Thomas, 482 U.S. 483 (1987); COLO. REV. STAT. 8-4-125 (1997), held preempted in Grohn v. Sisters of Charity Health Servs. Colo., 960 P.2d 722, 727-28 (Colo. Ct. App. 1998).

61. 532 U.S. 105 (2001).

62. 9 U.S.C. $\$ 1(2000)$.

63. 532 U.S. at 105 (noting that ejusdem generis requires that general words following specific ones in a statutory enumeration be construed to embrace only objects similar in nature to those objects enumerated by the preceding specific words). 
commentators over the exclusion's meaning all support this conclusion. ${ }^{64}$ The Supreme Court implicitly agreed that the language is ambiguous, since there would have been no need to resort to canons of statutory interpretation had the language been clear. Given the ambiguity, federalism principles dictated construing the provision in a manner that would preempt less state law. ${ }^{65}$ Instead, the Court extended the scope of arbitration agreements to which the FAA would apply and subjected more state law to Southland preemption, simply brushing aside the federalism issue. ${ }^{66}$

In general, preemption of state law stifles state "experimentation," not only by nullifying laws on the books, but also by discouraging proposals to change the law. Drafters of bills may forego desirable regulation of arbitration agreements, and FAA preemption gives legislative opponents of such measures additional ammunition. For example, the National Conference of Commissioners on Uniform State Laws was considering addressing issues relating to adhesive arbitration agreements in its Revised Uniform Arbitration Act, but determined that "the preemptive effect of the Federal Arbitration Act .... dramatically limits meaningful choices for drafters addressing adhesion contracts." ${ }^{67}$ In committee hearings on a California proposal to amend the state employment discrimination statute to prohibit the imposition of predispute arbitration agreements as a condition of employment, opponents argued that the bill "violates the Federal Arbitration Act." ${ }^{\circ 8}$

FAA preemption also tends to inhibit state decisional law. The section 2 savings clause has been construed to preserve general state contract-law defenses to arbitration agreements. ${ }^{69}$ Due largely to Southland's preemption doctrine, however, the case law has developed into a complex mixture of federal and state law. ${ }^{70}$ Some state courts, made skittish by the federal preemption issue looming around them, have tended to apply federal law to resolve state-

64. See infra Part III.B.2.

65. See supra notes $46-51$ and accompanying text. Regulation of the employment relationship is another area traditionally occupied by state law. See, e.g., Gade v. Nat't Solid Wastes Mgmt. Ass'n, 505 U.S. 88, 96 (1992).

66. The Court's assertion that Southland "is not directly implicated in this case," Circuit City, 532 U.S. at 122, is not a satisfactory answer. The issue in Circuit City was whether to extend Southland's preemption rule into an area of doubtful applicability. Without questioning Southland, the Court could and should have limited its damage by applying the restraining federalism principle of Gregory.

67. Nat'l Conf. of Comm'rs on Uniform State Laws, Adhesion Arbitration Agreements and the $R U A A$, at http://www.law.upenn.edu/bll/ulc/uarba/arbr0500.htm (last visited Aug. 25, 2003).

68. CAL. S. COMM. REP. NO. 1538, 2001-2002 Reg. Sess. (2002).

69. "State law may be applied" to invalidate or regulate an arbitration agreement, "if that law arose to govern issues concerning the validity, revocability, and enforceability of contracts generally." Doctor's Assocs. v. Casarotto, 517 U.S. 681, 686-87 (1996) (quoting Perry v. Thomas, 482 U.S. 483,492 n.9 (1987)). Indeed, a proper interpretation of the savings clause in section 2 is that all contract issues are to be resolved according to state law. See infra Part III.B.4.

70. See Charles Davant IV, Note, Tripping on the Threshold: Federal Courts' Failure to Observe Controlling State Law Under the Federal Arbitration Act, 51 DUKE L.J. 521, 539-41 (2001). 
law contract questions such as unconscionability. ${ }^{71}$ Some courts mistakenly believe that the FAA preempts even a general contract doctrine such as unconscionability when the latter is applied to an arbitration agreement. ${ }^{72}$ Finally, some courts in FAA cases have simply ignored applicable state-law principles and applied a general federal contract law reminiscent of the era of Swift v. Tyson. ${ }^{73}$ Such a mishmash of federal and state law is troubling if one holds genuine federalism concerns because it has a strong tendency to inhibit development of state decisional law and to displace more state law than is warranted.

III

\section{PREEMPTION AND THE ORIGINAL INTENT OF THE FAA}

Preemption is a question of congressional intent. ${ }^{74}$ In deciding whether the FAA created substantive law that preempts state limitations on arbitration agreements, Southland should have been guided by the original intent of the FAA. Instead, Southland flouted the FAA's historical record, which showed as clearly as possible, given the lack of explicit mention of preemption, that Congress intended the FAA to be a procedural statute that neither applies in state court nor preempts state law.

\section{A. The FAA's Legal Context}

The proximate historical concern underlying the passage of the FAA has been well explained. ${ }^{75}$ Arbitration agreements were deemed substantively valid insofar as an aggrieved party could in theory bring an action for damages for breach of an arbitration agreement. The problem lay in their enforcement. At common law, an arbitration agreement could not be the basis for a "plea in bar"- - essentially, a defense to a contract action requiring dismissal. Nor would courts of equity specifically enforce arbitration agreements or stay actions pending arbitration. Finally, courts deemed arbitration agreements to be revocable at the will of either party at any time before an arbitration award was enforced. ${ }^{76}$ These doctrines, which came to be known as "the old judicial hos-

71. See, e.g., GLF Constr. Corp. v. Recchi-GLF, 821 So. 2 d 372 (Fla. Dist. Ct. App. 2002) (applying federal law to a contractual waiver defense to an arbitration agreement); Munoz v. Green Tree Fin. Corp., 542 S.E.2d 360, 364-65 (S.C. 2001) (buttressing its unconscionability holding with federal authority).

72. See, e.g., Bradley v. Harris Research, 275 F.3d 884, 890 (9th Cir. 2001) (mistakenly concluding that the FAA preempted a state statute regulating contractual venue clauses).

73. 42 U.S. (16 Pet.) 1 (1842). In the notorious case of Hill v. Gateway 2000, 105 F.3d 1147 (7th Cir. 1997), for example, the court upheld against a consumer an arbitration agreement contained in shrinkwrap packaging on the box in which a mail-order computer was delivered. The court concluded the shrinkwrap form was a contract, without citing any state law of contract formation.

74. E.g., Retail Clerks v. Schermerhorn, 375 U.S. 96, 103 (1963) (stating that the "purpose of Congress is the ultimate touchstone" of the preemption doctrine).

75. See, e.g., Katherine Van Wezel Stone, Rustic Justice: Community and Coercion Under the Federal Arbitration Act, 77 N.C. L. REV. 931, 969-94 (1999); Schwartz, supra note 52, at 70-81.

76. See, e.g., Red Cross Line v. Atl. Fruit Co., 264 U.S. 109, 122-23 (1924); Kulukundis Shipping Co., S/A v. Amtorg Trading Corp., 126 F.2d 978, 981-84 (2d Cir. 1942); United States Asphalt Refining 
tility to arbitration," "77 were based primarily on the theory that an arbitration agreement was an "ouster of jurisdiction" of the court and therefore void or voidable as against public policy. ${ }^{78}$

The American Bar Association (ABA) and various business associations began promoting the passage of statutes to overrule this "ouster doctrine."79 Significantly, arbitration enforcement statutes, such as the New York Arbitration Act, on which the FAA was modeled, ${ }^{80}$ were deemed nonsubstantive law. There appears to have been an ambiguity in the contemporary legal understanding about whether arbitration agreements presented a question of procedure or a question of remedy. ${ }^{81}$ But the ambiguity really did not matter because both remedial and procedural matters were deemed to be lex fori-the law of the court-rather than lex loci-the substantive law of the jurisdiction. For both remedies and procedures, the prevailing principle was a federal rule for federal courts, and a state rule for state courts. ${ }^{82}$ There was a consensus that arbitration was not a matter of substantive law. ${ }^{83}$

Substantive law, in contrast to procedure and remedy, was lex loci, the law of the jurisdiction, but there was one significant wrinkle. Section 34 of the Judiciary Act of 1789, known as the Rules of Decision Act, provides that the "laws

Co. v. Trinidad Lake Petroleum Co., 222 F. 1006 (S.D.N.Y. 1915); JULIUS H. COHEN, COMMERCiAL ARBITRATION AND THE LAW 226-41 (1918); IAN R. MACNEIL, AMERICAN ARBITRATION LAW: REFORMATION, NATIONALIZATION, INTERNATIONALIZATION 20-21 (1992); Schwartz, supra note 52, at 73-75; Stone, supra note 75, at 973-76.

77. Kulukundis Shipping, 126 F.2d at 985 . While courts may have been hostile to enforcing arbitration agreements before the FAA, they were more receptive to enforcing arbitration awards. See MACNEIL, supra note 76, at 19.

78. Schwartz, supra note 52, at 74; Stone, supra note 75, at 976.

79. See Schwartz, supra note 52, at 75-81; Stone, supra note 75, at 979-91.

80. 1920 N.Y. Laws $275 \S 2$ (codified as New York Civil Practice Act $\S 1448$ ). The bill that became the FAA "follows the lines of the New York arbitration law enacted in 1920." S. REP. NO. 68-536, at 3 (1924).

81. Compare Red Cross Line, 264 U.S. at 122-23 (1924) (Brandeis, J.) ("The [New York] Arbitration Law deals merely with the remedy in the state courts .... It does not attempt either to modify the substantive maritime law or to deal with the remedy in courts of admiralty."), with Berkovitz v. Arbib \& Houlberg, Inc., 130 N.E. 288, 290 (N.Y. 1921) (Cardozo, J.) ("Arbitration is a form of procedure whereby differences may be settled. It is not a definition of the rights and wrongs out of which differences grow."). Both Red Cross Line and Berkovitz were construing the New York Arbitration Law of 1920.

82. See S. Pac. Co. v. Denton, 146 U.S. 202, 209 (1892) (“[W]henever Congress has legislated upon any matter of practice, and prescribed a definite rule for the government of its own courts, it is to that extent exclusive of the legislation of the state upon the same matter.").

83. See Julius Henry Cohen \& Kenneth Dayton, The New Federal Arbitration Law, 12 VA. L. REV. 265, 276 (1926). Cohen and Dayton wrote,

[W] hether or not a contract exists is a question of the substantive law of the jurisdiction wherein the contract was made. But whether or not an arbitration agreement is to be enforced is a question of the law of procedure and is determined by the law of the jurisdiction wherein the remedy is sought. That the enforcement of arbitration contracts is within the law of procedure as distinguished from substantive law is well settled by the decisions of our courts. 
of the several States, except where the Constitution, treaties, or statutes of the United States otherwise require or provide, shall be regarded as rules of decision in trials at common law, in the courts of the United States, in cases where they apply." ${ }^{\prime 4}$ This statute seems to require application of state substantive law in diversity cases, but prior to the Erie decision in 1938, federal courts sitting in diversity in cases at common law had given themselves a kind of substantive lawmaking power under the regime of Swift $v$. Tyson. ${ }^{85}$ Formally, the Supreme Court recognized that there was no such thing as federal common law, but Swift held that the phrase "laws of the several States" means a state's statutes, not its decisional law. In the absence of a controlling state statute, the Swift doctrine held, federal courts could exercise "independent judgment" on any substantive question of "general law," including commercial law, torts, and even property matters. ${ }^{86}$ Significantly, the prevailing judicial view under Swift held that the federal courts' power to declare legal principles of general law was not constrained by the limits on the legislative powers of Congress. Under the crabbed view of the Commerce Clause in this era, the Supreme Court would likely have found Congress to be without constitutional authority to legislate on most of the matters on which federal courts created general common law. ${ }^{87}$

\section{B. The FAA and its Legislative History}

The FAA was introduced in 1922 and enacted in $1925 .{ }^{88}$ It was originally intended as a procedural rule for the federal courts and was amended prior to passage to narrow its scope to exclude contracts not involving maritime or interstate commerce transactions. The idea that the FAA would apply in state courts or preempt state law was beyond the contemplation of Congress; it simply did not arise in the legislative history of the Act. ${ }^{89}$

84. Federal Judiciary Act of $1789 \S 34,1$ Stat. 73 (1790) (currently codified at 28 U.S.C. $\S 1652$ (2000)).

85. 42 U.S. (16 Pet.) 1 (1842).

86. Edward A. PURCEll, JR., Brandeis AND the Progressive CONSTITUTion 51-56 (2001). The theory was that courts, federal or state, were all similarly engaged in the process of attempting to discover the true, preexisting common law principle-the "brooding omnipresence" criticized by Holmes. See S. Pac. Co. v. Jensen, 244 U.S. 205, 222 (1917) (Holmes, J.) ("The common law is not a brooding omnipresence in the sky but the articulate voice of some sovereign or quasi sovereign that can be identified."); PURCELL, supra, at 51, 68-69, 78.

87. PURCELL, supra note 86 , at 54-58.

88. Identical federal arbitration bills were introduced simultaneously in the House and Senate during the Sixty-Seventh Congress. S. 4214, 67th Cong. (1922); H.R. 13522, 67th Cong. (1922); 65 CONG. ReC. 732, 797 (1922). Hearings were held, but neither bill came to a vote in committee. See Am. Bar Ass'n Comm. on Commerce, Trade and Commercial Law, The United States Arbitration Law and Its Application, 11 ABA JOURNAL 153, 155 (1925) [hereinafter ABA, Arbitration Law]. The bills were reintroduced in the Sixty-Eighth Congress in 1923 as S. 1005 and H.R. 646, and eventually enacted and signed into law just before the end of the Sixty-Eighth Congress, on February 14, 1925. See S. 1005, 68th Cong. (1925); H.R. 646, 68th Cong. (1925); 66 CONG. REC. 2761, 3003, 3276, 3748 (1925).

89. Professor Ian Macneil has written the leading scholarly account of the FAA's legislative history and critique of Southland's version of that history. MACNEIL, supra note 76, at 92-121, 138-47. Although comprehensive, Macneil's account does not take notice of the Walsh Amendment or the 


\section{The FAA as a Procedural Statute for Federal Courts}

It is plain that the federal arbitration bill was intended to provide procedural law for the federal courts. The House Report stated:

Whether an agreement for arbitration shall be enforced or not is a question of procedure to be determined by the law court [sic $]^{90}$ in which the proceeding is brought and not one of substantive law to be determined by the law of the forum in which the contract is made. Before such contracts could be enforced in the Federal courts, therefore, this law is essential. The bill declares that such agreements shall be recognized by the courts of the United States. ${ }^{91}$

The bill provided recognition and enforcement in "the courts of the United States." This phrase was synonymous with federal courts; state courts were not "courts of the United States," but rather "courts of the several states." House Report also restates the uncontroversial proposition that arbitration is forum law (lex fori) - albeit procedure, rather than remedy-and not substantive law. Why was this bill "essential" to make arbitration agreements enforceable in federal court? That assertion follows logically from the lex fori point: If arbitration clause enforcement were a matter of substantive law-lex loci-then a state arbitration statute should have been binding on federal courts sitting in diversity, even under Swift. ${ }^{93}$ Members of Congress were made well aware by the ABA proponents of the bill that parallel arbitration bills were being urged

other points discussed below. See infra Parts III.B.2-B.3. For a thought-provoking argument concluding that Southland reached a correct conclusion about the FAA's legislative history, see Christopher R. Drahozal, In Defense of Southland: Reexamining the Legislative History of the Federal Arbitration Act, 78 Notre Dame L. ReV. 101 (2002). In essence, Drahozal argues, in response to Macneil, that the legislative history is ambiguous about Congress's intent to preempt state law, but that the private lobbyists from the ABA who drafted the original bill and testified in its favor in committee hearings believed the FAA would apply in state court. While Drahozal makes some persuasive points, his argument does not engage with some of the plainest indications in the legislative history that Congress intended to make the FAA a procedural rule for the federal courts. See infra text accompanying notes 90-111. Moreover, the statements of lobbyist Julius Cohen on which Drahozal relies were in fact very ambiguous on whether the FAA would preempt state law. See infra note 111. Drahozal's premise that statements by lobbyists may legitimately be "imput[ed] ... to Congress" for purposes of determining legislative intent also seems dubious. See Drahozal, supra, at 107 n.38. Finally, even assuming that lobbyist intent can ever serve as a proxy for legislative intent, that contention is irrelevant here, since the ABA's version of the arbitration bill was amended by Congress to substantially narrow the Act's coverage. See infra text accompanying notes 100-09.

90. This is likely the third typographical error in the first two paragraphs of the Report and was probably intended to read "law of the court," which would then parallel the contrasting phrase "law of the forum" that follows. Either way, the meaning is plain.

91. H.R. REP. NO. 68-96, at 1 (1924). Furthermore, after summarizing the ouster rule, the Report states that "[t]he bill declares simply that such agreements for arbitration shall be enforced, and provides a procedure in the Federal courts for their enforcement." Id. at 2 (emphasis added).

92. See Southland Corp. v. Keating, 465 U.S. 1, 29 \& n.18 (O'Connor, J., dissenting); see also Rules of Decision Act, 28 U.S.C. $\$ 1652$ (2000) ("[T] he laws of the several states ... shall be regarded as rules of decision ... in the courts of the United States.”); Federal Employers' Liability Act § 1, 36 Stat. 291 (1910) ("[J]urisdiction of the courts of the United States under this chapter shall be concurrent with that of the courts of the several states.").

93. Again, the Swift doctrine allowed federal courts sitting in diversity to exercise independent judgment and diverge from state decisional law, but federal courts technically considered themselves bound to follow state statutes. See supra text accompanying notes 84-87. 
on state legislatures and had been adopted in a number of states. ${ }^{94}$ The federal bill was needed because these state statutes were lex fori and would therefore not be applied by federal courts. ${ }^{95}$

The nonsubstantive nature of the arbitration bill was reiterated in a floor statement by the sponsor of the House bill:

It does not involve any new principle of law except to provide a simple method by which the parties may be brought before the court in order to give enforcement to that which they have already agreed to.... It creates no new legislation, grants no new rights, except a remedy to enforce an agreement in commercial contracts and in admiralty contracts.

Courts and commentators interpreting the FAA in the decade following its enactment understood the statute as a matter of remedy or procedure applicable in federal court rather than as substantive law. ${ }^{97}$ In Marine Transit Corp. $v$. Dreyfus, ${ }^{98}$ for example, a party to an arbitration agreement challenged FAA enforcement on the argument that Congress had no authority to create equitable remedies-here, specific performance-in admiralty. The Court could have easily brushed this argument aside on the ground that Congress has the power to make substantive admiralty law, had the Court believed the FAA was in fact substantive law. Instead, the Court upheld the FAA as a permissible exercise of "[t]he general power of the Congress to provide remedies in matters falling within the admiralty jurisdiction of the federal courts, and to regulate their procedure." 99

94. See, e.g., Sales and Contracts to Sell in Interstate and Foreign Commerce, and Federal Commercial Arbitration: Hearing on S. 4213 and 4214 Before a Subcomm. of the Senate Comm. on the Judiciary, 67th Cong. 2 (1923) (statement of Charles L. Bernheimer, Chairman, Arbitration Comm., N.Y. Chamber of Commerce) ("The commercial bodies of the country have been urging the adoption of this principle of legislation throughout the country."); S. REP. NO. 68-536, at 3 (1924) ("The bill .. f follows the lines of the New York arbitration law enacted in 1920."); see also Stone, supra note 75, at 985-87 (detailing state adoptions of arbitration-enforcement statutes).

95. The House Report's assertion understandably glosses over a complicating point. Cases on the common law "side" of the federal docket were supposed to be litigated and tried, under the Conformity Act of 1872, according to procedures that "conform as near as may be" to the procedures of the courts of the state in which the federal court sat. Conformity Act of $1872 \S 5,17$ Stat. 197; see Nudd v. Burrows, 91 U.S. 426, 441-42 (1875). However, a specific federal procedural statute could supersede the Conformity Act to control common law practice. See S. Pac. Co. v. Denton, 146 U.S. 202, 209 (1892). In any event, since the whole point of the FAA was to authorize specific performance of arbitration agreements, the remedy and procedure questions in federal court would be addressed to its equity or admiralty jurisdiction, and state procedures were given no effect in federal courts sitting in admiralty or equity. See, e.g., Red Cross Line v. Atl. Fruit Co., 264 U.S. 109, 124 (1924) (admiralty); JoHn C. RoSE, JURISDICTION AND PROCEDURE OF THE FEDERAL COURTS 482-83 (1926) (equity).

96. 65 CONG. REC. 1931 (1924) (statement of Rep. Graham). Representative Graham chaired the House Judiciary Committee, which reported on the bill. See H.R. Rep. No. 68-96, at 1 (1924).

97. See MACNEIL, supra note 76, at 122-33.

98. 284 U.S. 263 (1932).

99. Id. at 278 (emphasis added); accord The Gerald A. Fagan, 49 F.2d 215, 216 (2d Cir. 1931) ("The Arbitration Act is a procedural statute and within the competency of Congress .... [It] is directed solely to a remedy"); Cities Serv. Oil Co. v. Am. Mineral Spirits Co., 22 F. Supp. 373 (S.D.N.Y. 1937) (holding that the FAA is procedural and therefore applies in diversity cases). For contemporary commentary construing the FAA as procedural, see Cohen \& Dayton, supra note 83, at 275-76; 6 S. 


\section{FAA Coverage: "Maritime Transactions" and "Contracts Involving Commerce"}

What of the argument, upon which Southland heavily relies, that Congress would not have imposed the "maritime" and "involving commerce" requirements in section 2 of the FAA unless it intended to create substantive law binding on the states? The answer is that the federal arbitration bill was initially intended to govern the procedure for a broad range of commercial contracts, including intrastate commercial contracts, but was amended to shrink the statute's coverage. As originally introduced in Congress, the bill that became the FAA provided:

Sec. 2. That a written provision in any contract or maritime transaction or transaction involving commerce to settle by arbitration a controversy thereafter arising between the parties out of such contract or transaction, or the refusal to perform the whole or any part thereof, or an agreement in writing to submit to arbitration an existing controversy arising out of such a contract, transaction, or refusal, shall be valid, irrevocable and enforceable, save upon such grounds as exist at law or in equity for the revocation of any contract. ${ }^{100}$

Significantly, Congress in this period lacked authority to enact substantive regulations of "any contract" outside of admiralty or interstate commerce, although federal courts could "discover" principles of general common law governing such contracts. ${ }^{101}$ The FAA could apply to "any contract" only if the law were procedural.

In May 1924, five months after the House Report was written, the Senate amended its version of the bill, which had been identical to the House version, by deleting the phrase "contract or" and inserting the phrase "contract evidencing a" before "transaction involving commerce."102 The amendments were made at the behest of Senator Thomas J. Walsh of Montana, a member of the Senate Judiciary Committee..$^{103}$ A progressive politician and former plaintiffs' lawyer, Walsh consistently supported legislation to curtail federal diversity jurisdiction and strip federal courts of jurisdiction to enter injunctions against labor unions and state utility rate boards. ${ }^{104} \mathrm{He}$ opposed the expansion of fed-

WILLISTON \& G. THOMPSON, LAW OF CONTRACTS 5368 (rev. ed. 1938) ("Inasmuch as arbitration acts are deemed procedural, the [FAA] applies only to the federal courts.").

100. H.R. 646, 65 CONG. REC. 11,081 (1924) (emphasis added).

101. See supra notes $85-87$ and accompanying text.

102. S. REP. NO. 68-536, at 1 (1924) (amending S. 1005). The House bill, H.R. 646, was substituted for the Senate bill and amended identically. See 66 CONG. REC. S 2759-61 (Jan. 31, 1925). Ultimately, H.R. 646, as amended by the Senate, was enacted into law. H.R. 646, 68th Cong. (1925) (enacted); see 66 CONG. REC. 3276, 3748 (1925).

103. 66 CONG. REC. S2761 (daily ed. Jan. 31, 1925).

104. PURCELL, supra note 86, at 31-32, 78. Abolition of diversity jurisdiction became a major progressive cause in this era because of the perceived pro-corporate bias of the federal courts. The federal common law developed under the Swift regime was largely favorable to corporate defendants, who were usually able to remove tort cases, insurance coverage disputes, and the like to federal court based on diversity jurisdiction. Federal courts aggressively used their equity powers to enjoin strikes and union activity, as well as to protect utility companies from rate regulation. And, of course, federal courts were active during this, the Lochner era, in striking down progressive economic and social legislation, at both the state and federal levels, on Commerce Clause and substantive due process grounds. 
eral law at the expense of state law, even to the extent of opposing the Rules Enabling Act, which terminated the applicability of state procedural law in federal court cases at law. ${ }^{105}$ In committee hearings on the FAA, Walsh had expressed concern that the bill might be applied in adhesive employment or insurance contracts. ${ }^{106}$ Significantly, controlling Supreme Court precedent at the time held that neither employment nor insurance contracts were contracts involving interstate commerce. ${ }^{107}$ Thus, by limiting the FAA to contracts involving admiralty and interstate commerce, Walsh's amendment would effectively exclude employment contracts and most insurance contracts from the FAA's coverage. $^{108}$ It is simply not plausible that an amendment proposed by Walsh would have been intended to expand the reach of the FAA and to preempt state law. Deleting the phrase "contracts or" only makes sense as a restriction on the scope of federal court cases that would be covered by the FAA. Specifically, the FAA as amended would be inapplicable to diversity cases not involving interstate or admiralty contracts. ${ }^{109}$

These activities produced a political backlash against the federal courts, in which, among other things, numerous bills were introduced in Congress to redress perceived abuses by the federal judiciary. These congressional attempts at redress included bills to abolish or limit diversity jurisdiction and to deprive courts of jurisdiction to issue injunctions in rate cases and labor cases, as well as bills seeking to overrule Supreme Court decisions. Id. at 77-91.

105. Id.

106. Hearing on S. 4213 and S. 4214 Before a Subcommittee of the Senate Comm. on the Judiciary, 67th Cong. 6 (1923) (remarks of Sen. Walsh). The Senate hearings were on S. 4214, which was identical to the House and Senate arbitration bills introduced in the next Congress and enacted as the FAA. See supra notes $88,102$.

107. See Hammer v. Dagenhart, 247 U.S. 251 (1918) (holding that intrastate employment is not "commerce" within Congress's regulatory power); Paul v. Virginia, 75 U.S. (8 Wall.) 168 (1868) (holding that insurance contracts were not interstate commerce); see also PURCELL, supra note 86, at 55.

108. Marine insurance contracts may still have been covered by the FAA as amended, but, as contracts between big business interests, they would not have been a particular concern to progressives like Walsh. Employment contracts in admiralty had already been excluded by the addition of the famous section 1 exclusion for "contracts of employment of seamen," in January 1923. See Letter from Herbert Hoover, Secretary of Commerce, to Senator Thomas Sterling (Jan. 23, 1923), reprinted in Hearing on S. 4213 and S. 4214 Before a Subcomm. of the Senate Comm. on the Judiciary, 67th Cong. 14 (1923).

109. The Walsh Amendment explains another apparent ambiguity seized upon by the Southland majority. The opening, typographical-error-laden sentence of the House Report states: "The purpose of this bill is to make valid and enforcible [sic] agreements for arbitration contained in contracts involving interstate commerce or within the jurisdiction or [sic] admiralty, or which may be the subject of litigation in the federal courts." H.R. REP. NO. 68-96, at 1 (1924). The Southland opinion makes much of the third "or," reading it to imply that "Congress had in mind something more than making arbitration agreements enforceable only in the federal courts." Southland Corp. v. Keating, 465 U.S. 1, 12-13 (1984). But that reading is strained and plainly contradicts the clear statements that follow in the Report to the effect that the FAA is procedural law for the federal courts.

Macneil argues that the third "or" is a typographical error that should be deleted. See MACNEIL, supra note 76, at 118. Even if it were not, there is a more likely interpretation than the Southland Court's, and one that is internally consistent with the rest of the House Report. The original version of the bill, quoted above, which was the subject of this Report, applied to "any contract or maritime transaction or transaction involving commerce...." H.R. 646, 68th Cong. (1925) (emphasis added); see supra note 100 and accompanying text. These three categories match the categories in the opening sentence of the House Report and refer to three categories of contract cases that might appear in federal court: (1) interstate contracts, (2) admiralty contracts, and (3) all other contracts that find their way into 
What of the House Report's statement that the FAA "is founded also upon the Federal control over interstate commerce and over admiralty" ?110 The Southland Court would read this statement as contradicting the immediately preceding assertion that the FAA is procedural law applicable in federal court. Congress's control over judicial procedure was primarily seen as based on its power to create lower federal courts under Article III, as amplified by the Necessary and Proper Clause. ${ }^{111}$ But there was then, and is today, nothing anomalous about Congress enacting a procedural or remedial statute, as opposed to substantive law, pursuant to its admiralty or commerce power. ${ }^{112}$ The word "also" in the House Report implies that interstate commerce and admiralty were being given as alternative grounds to enact a procedural rule for arbitration agreements.

\section{The Absence of Preemptive Intent}

Preemption doctrine in 1925 cut more deeply, yet more narrowly, than today. On one hand, the prevailing doctrine took the heavy-handed view that all preemption under the Commerce Clause was what would now be called "field" preemption: If Congress enacted a commerce regulation, then, unless it expressly saved state law, it was deemed to have occupied the field, and no state regulation on the same subject would be permitted. ${ }^{113}$ But the scope of federal preemption was limited by the narrow confines of the commerce power. In contrast, while the modern commerce power has greatly expanded, preemption doctrine has become comparatively more flexible toward the states. ${ }^{114}$ If Con-

federal court under diversity or pendent jurisdiction. The FAA was originally drafted, before the Walsh Amendment, as a blanket-procedural-rule to apply to all contracts that would come before the federal courts. See supra text accompanying note 100.

110. H.R. REP. No. 68-96, at 1 (1924); see Southland, 465 U.S. at 12-13 (quoting House Report).

111. Julius Cohen denied that "the proposed law depends entirely for its validity upon the exercise of the interstate-commerce and admiralty powers," and argued instead that "it rests upon the constitutional provision by which Congress is authorized to establish and control inferior Federal courts"Article III and the Necessary and Proper Clause. Cohen \& Dayton, supra note 83, at 275.

112. See, e.g., Marine Transit Corp. v. Dreyfus, 284 U.S. 263, 278 (1932) ("The general power of the Congress to provide remedies in matters falling within the admiralty jurisdiction of the federal courts, and to regulate their procedure is undisputed."). As the Second Circuit put it:

The Arbitration Act is a procedural statute and within the competency of Congress. Congress has the power "to make all Laws which shall be necessary and proper for carrying into Execution the foregoing Powers, and all other Powers vested by this Constitution in the Government of the United States, or in any Department or Officer thereof." Article 1, § 8, clause 18. This includes the power to establish courts, power over interstate and foreign commerce (article $1, \S 8$, clause 3 ), and jurisdiction over admiralty and maritime matters (article 3 , $\S 2$, clause 1 ). The Arbitration Act is directed solely to a remedy.

The Gerald A. Fagan, 49 F.2d 215, 216 (2d Cir. 1931) (emphasis added); see also infra Part V.A.2.

113. See N.Y. Cent. R.R. Co. v. Winfield, 244 U.S. 147 (1917) (holding that the Federal Employers' Liability Act preempted state personal injury law for railroad workers); Gardbaum, supra note 46, at 795-805.

114. See, e.g., Rice v. Santa Fe Elevator Corp., 331 U.S. 218, 230 (1947) ("[W]e start with the assumption that the historic police powers of the States were not to be superseded by the Federal Act unless that was the clear and manifest purpose of Congress."); Gardbaum, supra note 46, at 805-07. 
gress had indeed intended the FAA to be substantive law binding on the states, there would have been no question, in 1925, of state law applying to arbitration clauses in interstate contracts.

In the year before the FAA's passage, the principle that enforcement of arbitration agreements was not preemptive substantive law was definitively settled in the admiralty context by Red Cross Line v. Atlantic Fruit Co. ${ }^{115}$ State courts had (and have) concurrent jurisdiction over admiralty cases due to a savings clause in the jurisdictional statute. ${ }^{116}$ As the savings clause was construed, in light of the constitutional allocation of admiralty jurisdiction to the federal judicial power, state courts were bound to follow federal substantive law in admiralty cases but could apply their own law of procedure and remedy. ${ }^{117}$ In Red Cross Line, an admiralty dispute litigated in New York state court, the question was whether it was constitutionally permissible for the state court to apply the New York Arbitration Law. The Court concluded that the law "deals merely with the remedy in the state courts" and "does not attempt either to modify the substantive maritime law or to deal with the remedy in courts of admiralty." substantive law, its application to maritime contracts would have bound state courts in admiralty cases and preempted state law, and it would have effectively overruled Red Cross Line. Yet it apparently never occurred to any court applying the FAA that state arbitration laws might be preempted, in admiralty cases or otherwise. ${ }^{119}$

Nor, apparently, did preemption occur to Congress. Nothing in the legislative history suggests that states would be bound to apply section 2, or any section, of the FAA. On the contrary, the Senate Report asserts that the federal arbitration bill "follows the lines of the New York Arbitration Law enacted in $1920 \ldots$ and sustained by the decision of the Supreme Court of the United

115. 264 U.S. 109 (1924).

116. Section 24(3) of the Judicial Code granted federal district courts jurisdiction over "all causes of admiralty and maritime jurisdiction, saving to suitors in all cases the right of a common-law remedy." 28 U.S.C. $\S 1333$ (2000) (originally enacted as Act of June 10, 1922, ch. 216, § 1, 42 Stat. 634, 28 U.S.C. § 41(3) (1926)); see Washington v. W.C. Dawson \& Co., 264 U.S. 219, 221 nn.1-2 (1924). This feature of the admiralty savings clause is substantially the same today, preserving concurrent state court jurisdiction. See 28 U.S.C. § 1331(1); Lewis v. Lewis \& Clark Marine, Inc., 531 U.S. 438, 445 (2001) ("[T]he saving to suitors clause preserves remedies and the concurrent jurisdiction of state courts over some admiralty and maritime claims.").

117. Red Cross Line, 264 U.S. at 123-25; see W.C. Dawson \& Co., 264 U.S. at 221 nn.1-2 (holding that a state workmen's compensation law was substantive and therefore unconstitutional as applied to admiralty cases).

118. 264 U.S. at 124.

119. In the decade after the FAA's enactment, FAA preemption of state arbitration acts in federal cases involving interstate or maritime contracts was simply not discussed. Thus, for example, in Shanferoke Coal \& Supply Corp. v. Westchester Service Corp., 293 U.S. 449 (1935), the Court applied section 3 of the FAA to stay a federal diversity suit to allow the parties to a contract for the interstate sale of coal to arbitrate their dispute under the New York arbitration statute. There was no hint that the New York act might be preempted by the FAA. 
States in the matter of the Red Cross Line v. Atlantic Fruit Co." ${ }^{\prime 20}$ Conspicuously, the Senate Report does not say that the New York law would be preempted, that Red Cross Line would become a nullity, or that the Senate disagreed with the Court's conclusion that arbitration is a matter of remedy and not substantive law-let alone that Congress might be overruling Red Cross Line.

An illuminating comparison can be drawn between the FAA and two statutes of that era that did create substantive regulation intended to preempt state law. In the Federal Employers' Liability Act (FELA), ${ }^{121}$ governing the tort liability of interstate railroads to their injured employees, Congress abrogated the "fellow-servant" rule and replaced the harsh rule of contributory negligence as a complete bar to a plaintiff's recovery with a comparative negligence standard. ${ }^{122}$ Congress made plain that FELA was meant to apply in state courts and to supersede state law by providing that "any contract, rule, regulation or device whatsoever" that was inconsistent with the new statute was void, ${ }^{123}$ and that state courts would have concurrent jurisdiction with the federal courts. ${ }^{124}$ The Bill of Lading Act of 1916 imposed numerous notice and fairness requirements on shippers, regulated the content of bills of lading, and imposed liability for violations. ${ }^{125}$ This was substantive law for interstate contracts, and Congress indicated that it was fully aware of the implications. In a section addressing "the constitutionality of the pending bill," the Senate Report discussed at length the Supreme Court precedents recognizing complete preemption-in the language of the day, "exclusive" regulation-when Congress had substantively regulated interstate commerce. ${ }^{126}$ "[T]hese cases," the Report concluded, "show conclusively that if Congress passes this bill, it will supersede any and all state legislation upon the subject." ${ }^{127}$ The absence of any similar indications that the

120. S. REP. NO. 68-536, at 3 (1924).

121. Employers' Liability Act of 1908, c. 149, §§ 1-8, 35 Stat. 65 (codified at 45 U.S.C. $\S \S 51-60$ (2000)).

122. The "fellow-servant" doctrine shielded employers from liability when the injured party was harmed by the actions of a co-worker. See Joseph Slater, The Rise of Master-Servant and the Fall of Master Narrative: A Review of Labor Law in America, 15 BERKELEY J. EMP. \& LAB. L. 141, 152 (1994) (book review).

123. FELA $\S 5$ (codified at 45 U.S.C. $\S 55$ ). This provision was construed as binding state courts and preempting state law. See Vandalia R.R. Co. v. Sanders, 121 N.E. 275 (Ind. 1918); Hogarty v. Phila. \& Reading Ry. Co., 91 A. 854 (Pa. 1914).

124. Act of Apr. 5, 1910, c. $143 \S 1$, 36 Stat. 291 (codified at 45 U.S.C. $\S 56$ ) (amending FELA $\S 6$ ).

125. Bill of Lading Act of 1916, c. 415, 39 Stat. 538. A bill of lading is defined as "a bill in which it is stated that the goods are consigned or destined to a specified person." 49 U.S.C. $\$ 82$ (2000).

126. S. REP. NO. 64-149, at 5-7 (1916). An example providing such exclusive regulation was FELA.

127. Id. at 7; see also id. at 8 (asserting, in a series of rhetorical questions, that "the power of Congress is plenary after it has once assumed to legislate upon a given subject" and that "if Congress decides to regulate a bill of lading from the time it is issued until it is spent[,] it supersedes the authority of the State to control such bill in its transfer from one citizen of a State to another citizen within that State").

Julius H. Cohen and the ABA, as the nation's leading arbitration boosters, see Stone, supra note 75, at 979, may well have liked the FAA to apply as broadly as possible, including in state court, and therefore floated a hopeful trial balloon suggesting "probable" congressional power to preempt in this field. 
FAA was intended to bind state courts-either in the statute's text or its history-is telling.

\section{The Section 2 Savings Clause}

Out of its historical context, the phrasing of section 2-that arbitration agreements "shall be valid, irrevocable and enforceable"-takes on an almost biblical gravity, as though an arbitration agreement were as unbreakable as God's covenant with Abraham. Since the 1980s, the federal courts have at times seemed to treat arbitration agreements in this way. That, of course, misconstrues the statute's intended meaning.

Calling arbitration agreements "valid" simply restated existing judge-made law. As the Senate Report recognized, arbitration agreements were valid at law to the extent that an action in damages would lie for breach. ${ }^{128}$ The purpose of the FAA was to make these valid agreements enforceable, through a specific enforcement remedy combined with an order to stay proceedings in court. Again, whether called remedy or procedure, the concept captured in the term "enforceable" was not meant to be substantive law. Finally, the term "irrevocable" was not intended to elevate arbitration agreements to a special status untouchable by state law, but to address the other specific problem of the doctrine of the time - that an arbitration agreement "was subject to revocation by either party at any time before the award." 129 By eliminating this mutual and atwill revocability - which had placed arbitration agreements at a unique disadvantage compared to other contracts - the FAA put arbitration agreements "upon the same footing as other contracts," in the words of the House Report. ${ }^{130}$

Section 2 qualifies the assertion that arbitration agreements shall be "valid, irrevocable and enforceable" with the clause, "save upon such grounds as exist at law or in equity for the revocation of any contract." Grounds for the "revocation" of a contract include any issue of substantive contract law bearing on enforceability, including formation rules and defenses such as unconscionability. ${ }^{131}$ The Supreme Court has recognized in this "savings clause" "the purpose of Congress in $1925 \ldots$ to make arbitration agreements as enforceable as other

However, they conceded that the FAA merely "establishes a procedure in the Federal courts," adding that "[i]t is no infringement upon the right of each State to decide for itself what contracts shall or shall not exist under its laws." Cohen \& Dayton, supra note 83, at 276-77; ABA, Arbitration Law, supra note 88, at 154-55. Indeed, Cohen and the ABA were apparently sufficiently convinced that arbitration statutes were procedural law of the forum and not substantive law that they believed it would be necessary to enact a separate procedural statute for the federal system and each state. Such was the acknowledged game plan of the ABA. See ABA, Arbitration Law, supra note 88, at 156.

128. S. REP. NO. 68-536, at 2 (1924); see supra text accompanying note 95.

129. S. REP. NO. 68-536, at 2 (1924).

130. H.R. REP. NO. 6-96, at 1 (1924).

131. In contrast to "revocation" of an offer, "revocation" of a contract would mean, more generally, "the vacating of an instrument previously made," 2 BOUVIER's LAW DICTIONARY 2955 (8th ed. 1914), or "destroying or making void" the contract. See BLACK's LAW DICTIONARY 261-63, 1036 (2d ed. 1910). 
contracts, but not more so." ${ }^{132}$ More specifically, the FAA was intended to legislatively overrule the ouster doctrine, which created procedural or remedial hurdles to enforcement of otherwise valid arbitration agreements, in part through mutual and at-will revocability. ${ }^{133}$ The savings clause was intended to reinforce the principle that substantive contract law in general would not be affected by the FAA and would govern the question whether a valid arbitration agreement exists in the first instance. ${ }^{134}$

\section{IV}

\section{SOUTHLAND AS DYNAMIC STATUTORY INTERPRETATION: "FORUM} SHOPPING" AND THE "NATIONAL POLICY FAVORING ARBITRATION"

Whatever lip-service is paid to original intent as the proper basis for interpreting statutes, it is unrealistic to suppose that Southland would be overruled solely on the basis of its contradiction of Congress's original intent. Such a formalistic argument is unlikely to persuade because it fails to grapple with the terms on which the debate over the FAA's meaning will truly be decided. ${ }^{135}$ The following sections attempt to address these other possible terms of debate.

Southland provides an example of one aspect of "dynamic" statutory interpretation: attributing a policy or purpose to a statute to address issues not contemplated when the statute was enacted. ${ }^{136}$ Indeed, the decision might even be defended on the ground that, however modest the original FAA's scope may have been in 1925, it is permissible to interpret the statute broadly to address related but unanticipated issues and effectuate related but unanticipated policy judgments that arose in later times, so long as the interpretation is not contradicted by the statute's language or intent. Southland advances two such policy judgments: a policy against forum shopping and a national policy favoring arbi-

132. Prima Paint Corp. v. Flood \& Conklin Mfg. Co., 388 U.S. 395, 404 n.12 (1967).

133. H.R. REP. NO. 68-96, at 1-2 (1924); S. REP. NO. 68-536, at 2 (1924); see supra text accompanying notes $75-78,91$.

134. Where was this substantive law to come from? Under the Swift regime, the substantive law of contracts in the federal courts was largely federal or "general" common law, the decisional law of the federal courts. But state statutes governing contracts were also supposed to be applied in federal court. After 1938, Erie, of course, meant that the general federal law of contracts was abolished. Although it could be argued that the intent of the savings clause, drafted under the Swift regime, was to incorporate federal common law, such an interpretation is problematic because after Erie there would be no live federal common law to apply. A better construction is that the substantive law of contracts incorporated in the savings clause is whatever law exists at any given time. The FAA was to take its substantive contract law as it found it. As such, the general contract-law principles encompassed in the savings clause, post-Erie, would include not only state statutes, but also state decisional law. The Supreme Court reached that conclusion without difficulty, holding that the savings clause preserves state-law contract defenses of general applicability. "State law may be applied" to invalidate or regulate an arbitration agreement, "if that law arose to govern issues concerning the validity, revocability, and enforceability of contracts generally." Doctor's Assocs. v. Casarotto, 517 U.S. 681, 686-87 (1996) (quoting Perry v. Thomas, 482 U.S. 483, 492 n.9 (1987)).

135. "The practice of statutory interpretation does not follow any single inquiry (originalist or otherwise)." ESKRIDGE, supra note 9, at 13.

136. See id. at $48-60$. 
tration. This Part demonstrates that these policy arguments, on close analysis, are weakened-perhaps completely vitiated-by the Court's recent assertion that an arbitration clause is merely a form of forum-selection clause, with no impact on substantive rights. At the same time, the federalism values essentially ignored by Southland heavily outweigh Southland's dubious policy rationales.

\section{A. National Policy Against Forum Shopping?}

The Southland Court concluded that intolerable forum shopping would result if the same arbitration agreement could be enforced in federal diversity actions but not across the street in state court. Although the Court said it was "unwilling to attribute to Congress" an intent to allow such forum shopping, ${ }^{137}$ the Court's argument is plainly a judicial policy argument dressed as one of congressional intent. And as a matter of judicial policy, the Court's concern about such forum shopping was misplaced.

First, the problem is chimerical. When federal jurisdiction is present, both parties have equal access to federal court: the plaintiff by choosing where to file, and the defendant by removal. ${ }^{138}$ Thus, even if the FAA were construed as a procedural statute applicable only in federal court, there would really be no significant opportunity to forum shop-that is, to gain a litigation advantage unavailable to the adversary. ${ }^{139}$

Second, who has cause to complain about forum shopping in a situation in which the federal court would send the case into arbitration, while the state court would allow the case to be litigated? If the issue is one of clearing federal court dockets, then it is not a major concern to the federal courts that the state would preserve the judicial forum. If the issue is one of fairness to the parties, then it has to be recognized that predispute arbitration agreements (those that are almost invariably involved in enforcement disputes) are themselves a form of contractual forum shopping. The party drafting the typical predispute arbitration agreement seeks to control the forum choice by contract, and since the adhering party is typically hampered by a large disparity in bargaining power, information about the value of the future forum choice, or both, the drafting

137. Southland Corp. v. Keating, 465 U.S. 1, 15 (1984).

138. See 28 U.S.C. $\$ 1441$ (2000).

139. See Southland, 465 U.S. at 33-34 (1984) (O'Connor, J., dissenting). Justice O'Connor did not address the possibility of a plaintiff's keeping a case in state court by joining a nondiverse party as a defendant-for example, by adding an in-state employee as a defendant in a suit against an out-of-state corporation. But a plaintiff's ability to do this is limited to particular sets of facts and is likely to prove unsuccessful. The diverse corporate defendant could petition a district court separately under section 4 for an order staying litigation and compelling arbitration. Because the nondiverse in-state employee would not be a necessary party to the petition, the federal court would have diversity jurisdiction over it. 
party is able to forum shop at a bargain-basement price. ${ }^{140}$ Parties who impose such agreements should not be heard to cry "forum shopping."

Finally, forum shopping is a concern to judicial administration when the parties are able to shop for favorable substantive or outcome determinative rules; it is not a problem when substantive rights will not be affected. The Supreme Court has repeatedly asserted in its recent decisions that an arbitration clause is merely a specialized type of forum-selection clause that does not adversely affect anyone's substantive rights. ${ }^{141}$ Thus, the enforcement vel non of an arbitration agreement should not (theoretically) affect the outcome of a case-no more than would any forum-selection clause, under which the same substantive law would be applied by the alternate fora.

The possibility of a different enforcement decision being made by state and federal courts in the same state should be no more troubling than is a situation in which state and federal courts follow different conflict-of-laws heuristics in deciding whether to enforce a forum-selection clause. The Supreme Court has found this very situation to be entirely unproblematic. In Stewart Organization v. Ricoh Corp., ${ }^{142}$ for example, the Court held that a federal court sitting in diversity had to apply the federal venue statute, 28 U.S.C. $\S 1404($ a), rather than state law, in determining what effect to give a contractual venue clause. ${ }^{143}$ The Court was not troubled by the fact that the state court would have denied enforcement pursuant to a state policy disfavoring forum-selection clauses, whereas the federal doctrine viewed such agreements more favorably. Nothing in Stewart suggested that the federal procedural policy should somehow displace the Alabama rule in Alabama courts to prevent forum shopping. ${ }^{144}$ Inconsistencies in procedural regimes between state and federal court have long been an accepted feature of our legal system. Southland's concern about forum shopping has thus been vitiated by subsequent Supreme Court decisions that assume away any substantive effects of arbitral versus judicial fora.

\section{B. The "National Policy Favoring Arbitration"}

Case law holding arbitration agreements to be mere matters of forum selection without any impact on substantive rights also undermines the second policy justification. Since Moses H. Cone Memorial Hospital v. Mercury Construction Corp. ${ }^{145}$ it has become commonplace in judicial decisions concerning the FAA to assert that there is a "national policy favoring arbitration." ${ }^{146}$ It is widely recognized, though apparently not very troubling to the courts, that this policy

140. See James Zimmerman, Restrictions on Forum-Selection Clauses in Franchise Agreements and the Federal Arbitration Act: Is State Law Preempted?, 51 VAND. L. REV. 759, 760-61 (1998).

141. See infra text accompanying notes $150,189-96$.

142. 487 U.S. 22 (1988).

143. Id. at 32 .

144. See id. at 31-32.

145. 460 U.S. 1 (1983).

146. E.g., Southland Corp. v. Keating, 465 U.S. 1,10 (1984). 
was not the creation of the FAA as written by Congress, but was instead a judicial creation-federal common law-that took the FAA as a point of departure. ${ }^{147}$ If the basis for this policy is a general dislike of litigation, or of certain claims, or a belief that it is convenient to enforce arbitration agreements to reduce crowded court dockets, then the policy is nothing more than a thinlyveiled judicial value judgment. The Supreme Court has not said this, though in Circuit City Stores v. Adams it comes very close. ${ }^{148}$ That value choice is debatable, and it is arguably a choice for legislators, not courts, to make.

A more defensible jurisprudential argument is that of "dynamic" statutory interpretation. According to this argument, Congress all along meant to encourage arbitration as much as possible in enacting the FAA. While in 1925 that may have been limited to ordinary commercial disputes between merchants, the horizon of arbitration has expanded to include a much broader range of parties and claims. Alternatively, it can be argued that irrespective of the intent of Congress in 1925, the need to manage court caseloads and the recent trend favoring "alternative dispute resolution" justify courts in adapting statutory tools placed at their disposal.

The dynamic statutory interpretation argument is undermined by two flaws. First, Congress in 1925 did not intend to promote arbitration to the full extent of its power or anything like it. It could have enacted a substantive regulation of interstate commerce, preempting state law, but it did not; it could have written a procedural statute applicable to all contracts being litigated in federal court, whether in admiralty, federal question, or diversity, but it did not. It wrote a savings clause intended to preserve a significant role for general contract law and an exclusion clause designed to exempt employment contracts from FAA coverage. Thus, it cannot be said that the FAA has always been a "full reach" statute that the courts have simply expanded to keep pace with the expansion of the Commerce Clause.

Moreover, the federalism-based "clear-statement" rule of Gregory v. Ashcroft $^{149}$ dictates that the Court should not go far out in front of Congress in discovering national policies in silent statutes when the effect is such a largescale intrusion into state autonomy on a matter of traditional state regulation. Not only has Congress failed, in the FAA or otherwise, to identify alternative dispute resolution as a matter of pressing national concern that must be imposed on all levels of government, but on close inspection, one searches in

147. See Circuit City Stores v. Adams, 532 U.S. 105, 132 (2001) (Stevens, J., dissenting) ("There is little doubt that the Court's interpretation of the Act has given it a scope far beyond the expectations of the Congress that enacted it."); Allied-Bruce Terminix Cos. v. Dobson, 513 U.S. 265, 283 (1995) (O'Connor, J., concurring) ("[T]he Court has abandoned all pretense of ascertaining congressional intent with respect to the Federal Arbitration Act, building instead, case by case, an edifice of its own creation.").

148. See 532 U.S. at 122-23 (arguing that construing the FAA to apply to employment agreements is justified by the "real benefits to the enforcement of arbitration provisions" and by "the efficacy of alternative dispute resolution procedures adopted by many of the Nation's employers").

149. 501 U.S. 452, 461 (1991). 
vain for any strong federal policy that is affected by a state court's decision to, for instance, keep its courthouse doors open to state-law wage-and-hour claims. The Supreme Court has assured us that arbitration agreements have no impact on substantive rights. ${ }^{150}$ Like the choice between federal and state courts, the choice between court and arbitration, according to the Supreme Court, is a choice between two presumptively neutral and fair fora that are equally capable of applying the substantive law. A "national policy favoring arbitration," insofar as it is imposed on the states, is thus a federal policy requiring states to send a class of cases - those involving enforceable arbitration agreements-to arbitration rather than allow any of them into state courts. The federal interest in such close regulation of state dispute-resolution systems seems relatively weak.

The Southland majority may also have been motivated to use the FAA as a vehicle to impose a national pro-arbitration policy on the states out of a lack of confidence in the states' ability to find their own way toward alternative dispute resolution. Such "try it, you'll like it" paternalism, of course, does not fit with the values of the federalism revival. In any event, the mistrust of the states has proven unjustified. In general, most states have rigorously enforced arbitration agreements under state statutes similar to the FAA. ${ }^{151}$ State laws that create exceptions to an otherwise broad, general rule of enforcement-the laws preempted by Southland-are the kinds of variation that should be tolerated in a federal system that values the states' policymaking autonomy and experimentation.

Southland's creative attribution of policy rationales to the FAA might have been supportable if the issue were simply deciding the extent of the FAA's application in a close case-for example, whether trial of nonarbitrable issues should be stayed until intertwined arbitrable issues are resolved in arbitration..$^{152}$ But when the issue is the displacement of state law, with the resulting encroachment on important federalism values, the courts should be more careful with their policy attributions. Southland can be faulted for treading too carelessly over substantial federalism values in the name of questionable national policies.

150. Circuit City, 532 U.S. at 122-23; see infra text accompanying notes 189-96. While I have argued that the Court is wrong in this conclusion, see Schwartz, supra note 52, at 110-21, the Court has not seen fit to adopt my point of view.

151. See supra note 55.

152. See Dean Witter Reynolds, Inc. v. Byrd, 470 U.S. 213, 216 (1985) (holding that the policy favoring enforcement of arbitration agreements supported the rule that litigation should generally be stayed pending arbitration of intertwined claims). 


\section{$\mathrm{V}$ \\ SOUTHLAND AS DYNAMIC STATUTORY INTERPRETATION: “INTERVENING DEVELOPMENTS" IN THE FAA's HISTORY, 1938-1995}

The theory of dynamic statutory interpretation also recognizes that the evolution of relevant background law can essentially change a statute's meaning from its original intent. ${ }^{153}$ Justice Stevens seems to have been writing from this perspective in his separate Southland opinion when he allowed himself to be "persuaded that the intervening developments in the law compel the conclusion" that the FAA preempts some state laws, notwithstanding his conviction that "the 1925 Congress that enacted the statute viewed the statute as essentially procedural in nature." ${ }^{154} \mathrm{He}$ did not specify what these "intervening developments" are, but we can only assume that they include the two major postNew Deal legal developments that would bear on the FAA: the application of the Erie doctrine to the FAA and the emergence of a judicial nationalism that combined deference to legislative judgments on interstate commerce with a broad, nationalist orientation on such matters as federal labor law, civil rights, and federal jurisdiction. ${ }^{155}$ Both of these developments distorted the FAA in ways that directly contributed to Southland. But neither justifies continuing adherence to Southland.

\section{A. The Erie Problem in the FAA}

The present Southland conundrum is in large part the product of a sequence of missteps and non sequiturs in Supreme Court decisions attempting to resolve an Erie problem that never should have existed in the first place. In essence, the Supreme Court first declared that the FAA was "substantive" law for Erie purposes, and then, to make the FAA applicable in diversity cases, claimed that the FAA was based exclusively on the commerce power. Finally, in Southland, the Court concluded that any statute based on the commerce power must have been intended as substantive law binding on the states. Not only did each step in this progression involve either a mistake or a non sequitur, but the whole structure collapses when one realizes that the premise that began it all-that the arbitration enforcement is "outcome determinative"-has been expressly rejected in modern cases.

153. ESKRIDGE, supra note 9, at 61-68.

154. Southland Corp. v. Keating, 465 U.S. 1, 17 (1984) (Stevens, J., concurring in part and dissenting in part). Justice Stevens argued that the FAA preempts state laws limiting arbitration agreements in general, but that the savings clause preserves "certain substantive state policies that would be undermined by enforcing certain categories of arbitration clauses." Id. at 18 .

155. Professor Thomas Metzloff has suggested that the "ADR movement" is itself an intervening development that may have been on Justice Stevens's mind when he used this evocative phrase. E-mail from Thomas Metzloff, Professor of Law, Duke University School of Law, to David Schwartz, Assistant Professor of Law, University of Wisconsin Law School (Dec. 2, 2002, 10:16 EST) (on file with author). That suggestion was addressed above. See supra Part IV.B. 


\section{Misstep: Arbitration as "Outcome Determinative"}

The Supreme Court first considered the impact of Erie on the FAA in Bernhardt v. Polygraphic Co. ${ }^{156}$ The question presented was whether a district court in a diversity case could stay litigation and compel arbitration pursuant to section 3 of the FAA when the contract containing the arbitration clause fell outside the scope of section 2 of the Act. The Supreme Court reasonably answered that question in the negative. ${ }^{157}$ The Erie problem arose because the Court, while acknowledging that arbitration was a form of procedure, nevertheless determined that the law governing arbitration agreements was "substantive" for Erie purposes. Under Erie, as construed by Guaranty Trust Co. v. York ${ }^{158}$ a federal court sitting in diversity must apply state law on questions that "substantially affect the enforcement of the right as given by the state," lest "the outcome of litigation... depend on the courthouse where the suit was brought." 159 Accordingly, state law would necessarily govern such "outcome determinative" matters as whether the parties would have a judicial or arbitral forum. ${ }^{160}$ If section 3 could stand alone, then Bernhardt would force the Court to consider the thorny problem, suggested by Erie, of whether Congress has the authority to create substantive-that is, "outcome determinative"-rules of decision applicable in diversity cases in federal court. Indeed, the Bernhardt Court did consider whether a federal court could, as a federal judge-made procedural rule, compel arbitration in a diversity case in which the FAA did not apply-and determined under Erie that it could not. Of course, the Court could have simply construed the FAA as inapplicable to all diversity cases to avoid the Erie problem once and for all. ${ }^{161}$ By instead construing section 3 as inapplicable to the case at bar on the narrower ground that no "interstate" contract was involved, the Bernhardt Court expressly put off for another day the thorny constitutional question it had created: what would happen if a dispute on a contract that did involve interstate commerce-and therefore came within the scope of the FAA - appeared in federal court on diversity grounds $?^{162}$

156. 350 U.S. 198 (1956).

157. Reasoning that "[FAA] Sections 1, 2 and 3 are integral parts of a whole," the Court concluded that "the stay provided in $\S 3$ reaches only those contracts covered by $\S \S 1$ and 2." Id. at 201, 202. This reasoning is plainly correct, since it makes no sense to read section 3 as a stand-alone command to enforce arbitration agreements without supplying the courts a rule by which to enforce them.

158. 326 U.S. 99 (1947).

159. Bernhardt, 350 U.S. at 203 (citing Guaranty Trust, 326 U.S. at 108).

160. 350 U.S. at 204-05. Because it appeared that the arbitration agreement would not be enforceable under the law of Vermont, where the case was brought and where the contract was to be performed, the Supreme Court remanded the case to the district court to determine whether to apply Vermont law or the law of New York (the place of contracting), which would enforce the arbitration clause.

161. So Justice Frankfurter argued. Id. at 207-09 (Frankfurter, J., concurring).

162. Id. at 202 . 
2. Error: The Commerce Clause as the Exclusive Basis for the FAA

That question arose in Prima Paint Corp. v. Flood \& Conklin Manufacturing Co. ${ }^{163}$ a diversity action in which the plaintiff sought damages for fraud in the inducement of a contract. The lower courts and the Supreme Court agreed that the contract involved interstate commerce and therefore came within the FAA. The Supreme Court held further that the fraud claim was arbitrable and that, therefore, the suit should be stayed under section 3 until the claim could be arbitrated. ${ }^{164}$ The Court thus had to resolve whether it was constitutionally permissible to apply the FAA — now deemed "outcome determinative" under Bernhardt - in a diversity case. The Prima Paint Court reasoned that "[t]he question ... is not whether Congress may fashion federal substantive rules to govern questions arising in simple diversity cases," as Bernhardt had suggested, but rather "whether Congress may prescribe how federal courts are to conduct themselves with respect to subject matter over which Congress plainly has power to legislate." 165 The Court concluded that Congress clearly has such power under the Commerce Clause and that "it is clear beyond dispute that the federal arbitration statute is based upon and confined to the incontestable federal foundations of "control over interstate commerce and over admiralty.","166

Prima Paint's distinction between "simple diversity cases" and those raising "subject matter over which Congress plainly has power to legislate" addressed old, unfinished business of constitutional law stemming from Erie rather than creating a brave new Federal Arbitration Act. Erie's essential holding is that the federal courts are without power to create substantive rules of decision on "common law" matters on which Congress cannot, or has not chosen to, legislate. However, a jurisprudential disagreement subsequently emerged as to whether Erie also suggests that Congress lacks that power in diversity cases. ${ }^{167}$ The disagreement seems misplaced insofar as Erie should not have been read to imply any particular limits on the extent of Congress's power, other than the truism, of course, that Congress cannot make substantive rules-for the federal courts or otherwise-on matters beyond its enumerated powers. ${ }^{168}$ Thus, Erie

163. 388 U.S. 395 (1966).

164. Id. at 403-04.

165. Prima Paint, 388 U.S. at 404-05.

166. Id. at 405 (emphasis added) (quoting H.R. REP. No. 68-96, at 1 (1924); S. REP. No. 68-536, at 3 (1924)).

167. Compare Erie R.R. Co. v. Tompkins, 304 U.S. 64, 78 (1938) ("Congress has no power to declare substantive rules of common law applicable in a state."), with id. at 91-92 (Reed, J., concurring) ("If the opinion commits this Court to the position that the Congress is without power to declare what rules of substantive law shall govern the federal courts, that conclusion also seems questionable."). Chief Justice Stone commented to Justice Roberts in 1941 that Erie "had not settled the issue of whether Congress could enact substantive rules of law for the federal courts in diversity suits "notwithstanding some unfortunate dicta in the opinion." PURCELL, supra note 86, at 202 (quoting Letter from Harlan F. Stone to Owen J. Roberts (Jan. 3, 1941)).

168. In context, Erie's "Congress has no power" language refers only to the doctrine of enumerated powers. See Erie, 304 U.S. at 78. To begin with, Erie involved subject matter that was plainly within 
confirms the uncontroversial notion that Congress cannot enact "substantive" rules of decision in diversity cases involving purely state-law rights on matters beyond the enumerated powers_-"simple diversity cases" in the words of Prima Paint.

Prima Paint addressed the related but different question of whether Congress can enact substantive, or "outcome determinative," rules of decision to apply in diversity cases concerning matters within its enumerated powers. Can Congress "prescribe how federal courts are to conduct themselves with respect to subject matter over which Congress plainly has power to legislate"-for instance, under the commerce clause? The Prima Paint Court answered "yes." 169 There was no need to find in the FAA an intent to create a substantive right, one that would be enforceable in state court, and preempt state law, to hold that the FAA created a substantive or outcome determinative rule applicable in federal court. And the Prima Paint Court did not take that step, holding only that "[f]ederal courts are bound to apply rules enacted by Congress with respect to matters-here, a contract involving commerce-over which it has legislative power." ${ }^{\prime 170}$ Indeed, Prima Paint seems to hew to the notion that the FAA, though outcome determinative, is procedural law: a set of rules "prescrib[ing] how federal courts are to conduct themselves" rather than "substantive rules to govern . . . simple diversity cases."171

There is nothing strange about this aspect of Prima Paint. Since Hanna $v$. Plumer, ${ }^{172}$ decided a year before Prima Paint, it has been established that federal courts will apply federal rules that are in some sense "substantive" and that may differ from the state law "across the street." In Hanna, the Court held that a federal procedural rule was applicable in a diversity case to keep a plaintiff's claim alive, notwithstanding that the governing state rule would have mandated dismissal and that the choice of law was therefore "outcome determinative."173 Because a valid congressional enactment applied to the situation, ${ }^{174}$ there was no

Congress's enumerated powers. Although Tompkins was not a railroad employee, and therefore did not come within any existing federal statute, the consitutionality of FELA left little doubt that Congress clearly did have the power to enact legislation to cover injuries caused by railroads-even under the pre-New Deal understanding of the Commerce Clause. See The Second Employers' Liability Cases, 223 U.S. 1, 51-52 (1912) (upholding FELA as a permissible commerce regulation). Further, Erie elsewhere faults Swift for its assumption of "power to declare rules of decision which Congress was confessedly without power to enact as statutes." Erie, 304 U.S. at 72. The thrust of the opinion was the Court's own assertion of unconstitutional lawmaking power, not any such assertion by Congress. In context, Congress's lack of power to impose "common law" on the states meant it could not impose "non-statutory law"- that is, Congress could not issue a broad, general authorization to federal courts to make general, non-statutory law extending beyond its enumerated powers. See PURCELL, supra note 86, at 178-80, 202.

169. See 388 U.S. at 405.

170. Id. at 406.

171. Id. at 405 (emphasis added).

172. 380 U.S. 460 (1965).

173. 380 U.S. at 466-67.

174. The Congressional enactment was the Rules Enabling Act, 28 U.S.C. $\$ 2072$ (2000), which authorized the promulgation of the Federal Rules. See Hanna, 380 U.S. at 464. 
Erie problem, period. Even though the Erie doctrine was understood to prohibit Congress from "fashion[ing] rules which are not supported by a grant of federal authority contained in ... the Constitution," its offspring cast no doubt on the long-recognized power of Congress to prescribe housekeeping rules for federal courts even though some of those rules will inevitably differ from comparable state rules." 176 This power over "housekeeping" rules, the Court has subsequently explained, "falls comfortably within Congress's powers under Article III as augmented by the Necessary and Proper Clause." 177 What Hanna v. Plumer held in the context of a procedural law enacted pursuant to Article III, Prima Paint held in the context of a law that seemed to fall "within the uncertain area between substance and procedure," enacted (so the Prima Paint Court said) pursuant to the commerce power. This feature of federal law continues to the present day: if a federal statute comes within the powers of Congress, it binds the federal courts, and no Erie problem is raised by the application of a different rule in state court, even though the rule may be in some sense substantive or outcome determinative. ${ }^{179}$

The Prima Paint Court erred, however, in asserting that the FAA's basis was "confined to" Congress's interstate commerce and admiralty power. That assertion is flat out wrong: As we have seen, the legislative history shows that Congress placed primary reliance for enacting the FAA on its control over the procedures of the federal courts. ${ }^{180}$ In Prima Paint, however, the Court stopped short of making the more far-reaching error of suggesting that reliance on the Commerce Clause necessarily implied an intent to impose federal substantive law on the states. That error that would be made in Moses H. Cone and Southland.

3. Non Sequitur: From Commerce Clause to Substantive Law

Although Southland builds on Prima Paint's error in attributing the FAA solely to Congress's interstate commerce and admiralty powers, Southland did not follow inexorably from Prima Paint. It is, on the contrary, a non sequitur. Prima Paint could and should have been understood as clarifying that the Commerce Clause, no less than Article III and the Necessary and Proper Clause, can be the basis for a federal rule applicable in federal but not state courts. But in Southland, the Court trampled over this clarification. The Southland Court began its preemption analysis with Prima Paint's (partially mistaken) determination that Congress rested the FAA on "its broad power to

175. 380 U.S. at 471.

176. Id. at 473 .

177. Stewart Org. v. Ricoh Corp., 487 U.S. 22, 32 (1988).

178. Hanna, 380 U.S. at 472.

179. See Stewart Org., 487 U.S. at 32 n.11 ("Because a validly enacted Act of Congress controls the issue in dispute"-whether a federal court would enforce a contractual venue clause which would be invalid in state court-"we have no occasion to evaluate the impact of application of federal judgemade law on the 'twin aims' that animate the Erie doctrine.").

180. See supra Part III.B.2. 
enact substantive rules under the Commerce Clause."181 These statements from Prima Paint, according to the Southland majority, "clearly implied that the substantive rules of the Act were to apply in state as well as federal courts." "As shown above, however, they "clearly implied" nothing of the sort. It may be true, as the Southland majority went on to say, that when Congress exercises its commerce power, it "normally" creates substantive regulations applicable in state as well as federal courts. ${ }^{183}$ But, as Justice Black's dissent in Prima Paint pointed out, the creation of substantive rights "normally" goes hand-in-hand with the creation of federal subject matter jurisdiction, and the absence of such jurisdiction shows that the FAA is not the "normal" exercise of commerce power the Southland majority wished to make it. ${ }^{184}$

More importantly, Southland's assertion that Congress necessarily binds the states and broadly preempts inconsistent state policies whenever it acts pursuant to the Commerce Clause is very bad federalism and plainly wrong as a matter of constitutional law. To begin with, it is inconsistent with modern preemption doctrine, which has expressly replaced presumed preemption with a congressional intent approach. ${ }^{185}$ Under the modern approach, Congress can decide not to preempt state law at all, or to "save" state law, in whole or in part, when it legislates under the Commerce Clause. Assuming for the sake of argument that section 2 is substantive law, a natural reading of the savings clause would be that state substantive law is preserved, at least in state court. Furthermore, Southland goes badly astray by implying that only by invoking the heavy hand of preemption can Congress avoid constitutional infirmity under Erie-that the Erie principle is violated by a substantive federal rule applicable in diversity cases but not binding on the states, so that Erie requires making such a rule a full-blown federal substantive right. That would be ironic indeed in light of Erie's federalist purpose to preserve state lawmaking autonomy. ${ }^{186}$

Finally, it cannot be overlooked that the Supreme Court had bookended the FAA's enactment with its decisions in Red Cross Line and Marine Transit, both of which held that arbitration-enforcement statutes - the New York Arbitration Law, on which the FAA was patterned, and later the FAA itself-are not substantive law. ${ }^{187}$ Bernhardt was consistent with these decisions, merely updating

181. Southland Corp. v. Keating, 465 U.S. 1, 11 (1984).

182. Id. at 12 .

183. $I d$.

184. It is ironic that the Southland majority opinion relies on Justice Black's dissent for the proposition that exercise of the commerce power normally implies preemptive effect in state court. Id. at 12 (citing Prima Paint Corp. v. Flood \& Conklin Mfg. Co., 388 U.S. 395, 420 (1967) (Black, J., dissenting)). Justice Black was arguing that, because federal question jurisdiction "normally" arises from federal substantive law, the absence of federal question jurisdiction under the FAA "militate[s] against the view that Congress was creating a body of federal substantive law." Prima Paint, 388 U.S. at 420 (Black, J., dissenting) (emphasis added). Here we have an excellent example of standing an argument on its head.

185. See supra text accompanying notes 113-114.

186. Erie R.R. Co. v. Tompkins, 304 U.S. 64, 78-79 (1938).

187. See supra notes 98,115 . 
them in post-Erie terms by holding that arbitration enforcement, while procedural in form, is substantive in effect because it is outcome determinative. Prima Paint was likewise consistent with these precedents: It merely held that Congress's authority to enact substantive law under the Commerce Clause encompasses the lesser-included power to enact quasi-substantive rules of procedure governing federal courts. But Southland's leap from Prima Paint to a holding that the FAA is substantive law binding on the states departed from this line of cases and sub silentio overruled Red Cross Line and Marine Transit.

4. The Illusory Erie Problem: The FAA Is Not Substantive Law After All

The Erie problem was conjured into existence only by Bernhardt's conclusion that arbitration enforcement is outcome determinative and therefore substantive law for Erie purposes. Bernhardt acknowledged that the FAA is at least formally procedural, a conclusion consistent with the legal understanding of the FAA, both in the courts and Congress, prior to Erie. ${ }^{188}$ Had Bernhardt decided that the FAA was not outcome determinative, there would have been no problem applying it in diversity cases and no need for the Prima Paint Court to state, incorrectly, that the FAA's basis is "confined to" the Commerce Clause. Far more disturbing, however, is that the Erie problem identified in Bernhardt and solved in Prima Paint no longer exists because the premise on which it was based-Bernhardt's conclusion that the FAA is outcome determinative-is no longer good law.

Bernhardt's characterization of the FAA as "outcome determinative" was based on Wilko v. Swan, ${ }^{189}$ a 1953 decision holding that the right to a judicial forum in federal Securities Act cases is "a substantial right" and therefore nonwaivable under a substantive anti-waiver provision of the Securities Act. ${ }^{190}$ Bernhardt, tracking a nearly identical passage in Wilko, opined that arbitration enforcement is substantive in its implications because arbitration is an inferior form of dispute resolution for important substantive claims. Enforcement of an arbitration clause could therefore have a substantive effect on the outcome of legal disputes. ${ }^{191}$ But Wilko has since been overruled on this very point. Its "general suspicion of the desirability of arbitration and the competence of arbi-

188. See supra notes 156-62 and accompanying text.

189. 346 U.S. 427 (1953), overruled by Rodriguez de Quijas v. Shearson/Am. Express, 490 U.S. 477 (1989).

190. Section 14 of the Securities Act of 1933, 15 U.S.C. $\$ 77$ n (2000), prohibits any "condition, stipulation, or provision" that purports to require a securities purchaser to "waive [the seller's] compliance with any provision." Wilko construed this section as prohibiting enforcement of arbitration agreements because they waive the right to a judicial forum. See 346 U.S. at 434-35.

191. The Bernhardt Court opined,

[T]he remedy by arbitration, whatever its merits or shortcomings, substantially affects the cause of action created by the State. . . Arbitrators do not have the benefit of judicial instruction on the law; they need not give their reasons for their results; the record of their proceedings is not as complete as it is in a court trial; and judicial review of an award is more limited than judicial review of a trial—all as discussed in Wilko v. Swan ....

Bernhardt v. Polygraphic Co., 350 U.S. 198, 203 (1956) (citing Wilko, 346 U.S. at 435-38). 
tral tribunals" 192 has been deemed "far out of step with our current strong endorsement" of arbitration under the FAA. ${ }^{193}$ The Court has specifically rejected Wilko's determination that arbitration affects substantive rights, calling the selection of an arbitral versus a judicial forum merely "procedural." 194 The Court's recent FAA cases repeatedly assert that arbitration agreements are "in effect, a specialized kind of forum-selection clause" $" 195$ and that a party compelled to arbitrate "does not forgo ... substantive rights" but "only submits to their resolution in an arbitral, rather than a judicial, forum."196

In retrospect, the Bernhardt Court was in error-at least in light of current doctrine-in holding arbitration enforcement to be an outcome determinative, and therefore substantive, right. There need not have been any Erie problem to prompt the Court to look for substantive congressional authority for the FAA. And Prima Paint compounded the mistake by stating in terms far too strong in light of the legislative history that the FAA was confined to Congress's commerce power. Southland took this error-built-upon-error and added a non sequitur: If Congress acted under the commerce power, it must have done so with the intent to exercise that power against the states to the fullest, to create substantive law enforceable in state court and to preempt contrary state law. In so holding, Southland is squarely inconsistent with the current line of cases holding that enforcement of arbitration agreements has no impact on substantive rights.

\section{B. The Judicial Nationalist Revision of the FAA}

A second set of intervening developments that might be seen as justifying Southland under a dynamic theory of statutory construction is a parallel history of substantive-law federalism that distorted the FAA no less than the Court's struggles with the Erie doctrine. This does not refer to the dramatic expansion of what the courts accepted as the legitimate scope of the commerce power, whose impact on the interpretation of the FAA has been relatively easy to perceive. $^{197}$ More subtle, but equally far-reaching, has been the impact of the civil

192. Shearson/Am. Express v. McMahon, 482 U.S. 220, 231 (1987) (questioning and limiting Wilko).

193. Rodriguez de Quijas v. Shearson/Am. Express, 490 U.S. 477, 481 (1989) (overruling Wilko).

194. Id. at 482 .

195. Id. at 482-83 (quoting Scherk v. Alberto-Culver Co., 417 U.S. 506, 519 (1974)); accord EEOC v. Waffle House, 534 U.S. 279, 296 (2002) (holding that an arbitration agreement is "effectively a forum selection clause").

196. E.g., Gilmer v. Interstate/Johnson Lane Corp., 500 U.S. 20, 26 (1991) (quoting Mitsubishi Motors Corp. v. Soler Chrysler-Plymouth, Inc., 473 U.S. 614, 628 (1985)), quoted in Circuit City Stores v. Adams, 532 U.S. 105, 123 (2001).

197. It is generally accepted that in 1925 Congress held a view of its commerce power that was relatively consonant with the narrow parameters to which the Supreme Court tried to hold it prior to 1937. In modern times, the courts expanded the scope of the FAA to keep pace with the expansion of the commerce power, and in 1995, in Allied-Bruce, the Supreme Court held that the coverage language applying the FAA to any "contract evidencing a transaction involving commerce" extended, in essence, to any contract affecting interstate commerce, the broadest possible reach the statute could have. See Allied-Bruce Terminix Cos. v. Dobson, 513 U.S. 265, 277 (1995). That expansion did not occur all at 
rights-oriented judicial nationalism of the 1950s through 1970s. Two prominent features of this trend were the Court's somewhat mistrustful attitude toward state governments and state courts and its furtherance of the nationalization of labor law. The judicial nationalism of this era left a deep imprint on the FAA through two instances of result-oriented and strained statutory interpretation.

\section{Judicial Nationalism, the FAA, and Federal Labor Law}

A significant chapter in the FAA's transformation from a procedural statute into a broad, substantive federal policy is its intertwining with federal labor law. By the 1940s, arbitration of disputes under collective bargaining agreements had emerged as a contractual tradeoff for the right to strike. ${ }^{198}$ Labor unions resorted to the courts with increasing frequency to seek enforcement of arbitration provisions in collective bargaining agreements, arguing in some cases that the FAA mandated enforcement. ${ }^{199}$ Following the enactment of the Labor Management Relations Act (LMRA) ${ }^{200}$-also known as the Taft-Hartley Actin 1947, the lower federal courts divided sharply over whether and how labor arbitration agreements could be enforced. Some lower courts found, by implication from section 301 of the LMRA, the judicial power to stay litigation, order arbitration, and confirm arbitration awards. ${ }^{201}$ Other courts were reluctant to do so, finding the FAA to be safer statutory ground..$^{202}$ It may be difficult today to appreciate the magnitude of this issue, on which nothing less than nationwide freedom from industrial strife seemed to be at stake. Given the doubts about the applicability of section 301 of the LMRA, courts and commen-

once. Compare Bernhardt v. Polygraphic Co., 350 U.S. 198, 200-01 (1956) (holding that a contract made in New York for a sales representative to be employed in Vermont did not involve interstate commerce), with Circuit City Stores, 532 U.S. at 105 (holding that an intrastate employment contract for a retail store employee is covered by the FAA as a contract involving commerce).

198. See Archibald Cox, Grievance Arbitration in the Federal Courts, 67 HARV. L. REV. 591 (1954); see also Steelworkers v. Am. Mfg. Co., 363 U.S. 564, 567-68 (1960) (stating that arbitration is a quid pro quo for the right to strike).

199. Unions sought enforcement of arbitration agreements in three contexts: to stay employer damages suits for breaches of no-strike agreements, see, e.g., Tenney Eng'g v. United Elec. Radio \& Mach. Workers, 207 F.2d 450 (3d Cir. 1953) (en banc); to compel the employer's participation in grievance arbitration, see, e.g., Amalgated Ass'n of Street, Elec. Ry. \& Motor Coach Employees v. Penn. Greyhound Lines, 192 F.2d 310 (3d Cir. 1952); and to enforce arbitration awards, see, e.g., Mercury Oil Ref. Co. v. Oil Workers Int'l Union, 187 F.2d 980, 983 (10th Cir. 1951).

200. 29 U.S.C. $\S \S 141-44,151-67,171-83,185-87,557$ (2000).

201. See, e.g., Textile Workers v. Am. Thread Co., 113 F. Supp. 137, 142 (D. Mass. 1953); Evening Star Newspaper Co. v. Columbia Typographical Union, 124 F. Supp. 322 (D.D.C. 1954).

202. See Signal-Stat Corp. v. United Elec., 235 F.2d 298, 301 (2d Cir. 1956) (holding that because the FAA applied to a labor arbitration agreement, "[we] need not decide, whether the arbitration agreement is enforceable under Section 301"). Other courts held both section 301 of the LMRA and the FAA inapplicable, concluding that collective bargaining agreements are "contracts of employment of ... workers engaged in foreign or interstate commerce" excluded from FAA coverage under section 1. See, e.g., Hoover Motor Express Co. v. Teamsters, 217 F.2d 49, 52 (6th Cir. 1954). 
tators alike "strove mightily" to find theories by which the FAA would apply to enforce labor arbitration agreements. ${ }^{203}$

The Supreme Court eventually decided the issue in Textile Workers Union $v$. Lincoln Mills, ${ }^{204}$ holding that section 301(a) of the LMRA granted jurisdiction in the federal courts to create a body of substantive federal law of labor arbitration, including the power to compel arbitration, that "the courts must fashion from the policy of our national labor laws." ${ }^{205}$ Though the question of the applicability of the FAA was before the Court, the majority opinion did not mention the FAA one way or the other, leaving disagreement over the FAA's applicability to linger in the lower courts. ${ }^{206}$ While the question has become somewhat academic, the FAA's applicability to labor arbitration has never been resolved. Moreover, by approving the federal courts' practice of "look[ing] to the [FAA] for guidance in labor arbitration cases," 207 the Supreme Court has, wittingly or not, reinforced the nationalist pull of federal labor law on the FAA. Had the Court taken the opportunity in Lincoln Mills to divorce the FAA from federal labor law, there would have been less historical impetus to turn the FAA into a federal policy preemptive of state law. ${ }^{208}$

203. Samuel Estreicher, Predispute Agreements to Arbitrate Statutory Employment Claims, 72 N.Y.U. L. REV. 1344, 1368 (1997); see Cox, supra note 198, at 593 (devising theories to support application of the FAA to collective bargaining agreements). The leading case applying the FAA to labor arbitration agreements was Tenney Engineering v. United Electrical Radio and Machine Workers, 207 F.2d 450 (3d Cir. 1953) (en banc), whose reasoning has been regarded as strained both then and now. See Cox, supra note 198, at 606; Estreicher, supra, at 1368. The problem with these arguments, of course, is the extensive historical record to the effect that the FAA was not intended to apply to labor or employment contracts. See, e.g., Textile Workers Union v. Lincoln Mills, 353 U.S. 448, 466-67 (1957) (Frankfurter, J., dissenting); Craft v. Campbell Soup Co., 177 F.3d 1083, 1085-92 (9th Cir. 1998), overruled by Circuit City Stores v. Adams, 532 U.S. 105 (2001); Matthew W. Finkin, "Workers' Contracts" Under the United States Arbitration Act: An Essay in Historical Clarification, 17 BERKELEY J. EMPL. \& LAB. L. 282 (1997). Nevertheless, result-oriented courts applied the FAA to labor arbitration by holding that the employment contracts exclusion in section 1 should be construed narrowly to apply only to transportation workers. The Lincoln Mills decision should have "removed the need for such creative readings," Estreicher, supra, at 1367, but Tenney was adapted and followed in later decades by courts that wanted to enforce arbitration agreements in individual employment contracts, culminating in the Supreme Court's recent Circuit City decision. See supra text accompanying notes 61-66.

204. 353 U.S. 448 (1957).

205. Id. at 456 .

206. Compare Miller v. Public Storage, 121 F.3d 215, 218 (5th Cir. 1997) (holding that the FAA does not apply to collective bargaining agreements), with Md. Cas. Co. v. Realty Advisory Bd., 107 F.3d 979, 982 (2d Cir. 1997) (holding that the FAA applies to collective bargaining agreements except where the narrow section 1 "workers" exclusion applies).

207. United Paperworkers Int'l Union v. Misco, Inc., 484 U.S. 29, 40 n.9 (1987).

208. Justice Frankfurter, dissenting in Lincoln Mills, argued that the FAA does not apply to labor disputes and that the majority's failure to rely on or mention the FAA implied agreement on that point: "I would make this rejection [of the FAA] explicit ...." 353 U.S. at 466 (Frankfurter, J., dissenting).

In United Steelworkers v. Warrior \& Gulf Navigation Co., 363 U.S. 574 (1960), the Court took pains-although, again, without mentioning the FAA expressly - to distinguish labor arbitration from "commercial" arbitration. See id. at 578 (distinguishing Wilko v. Swan, 346 U.S. 427 (1953)). 


\section{Judicial Nationalism, the FAA, and Moses H. Cone Memorial Hospital}

Civil rights-oriented judicial nationalism, whose heyday is indelibly associated with the Warren Court era, might be broadly characterized by a mistrust of state courts and state institutions and a reliance on federal courts as a primary forum for enforcement of civil rights. A corollary of the latter trend is the perceived need to keep the federal courthouse doors open to civil rights claimants. The federal judiciary has always been divided on these substantive values, of course, and the judicial battles over substance in this era were frequently encoded as controversies over technical doctrines of federal procedure and jurisdiction, such as standing and the power of federal courts to enjoin state litigation. ${ }^{209}$

These two strands of judicial nationalism-revolving around labor and civil rights-are historically intertwined. They came together with the FAA in Moses H. Cone Memorial Hospital v. Mercury Construction Corp. ${ }^{210}$ The case originated as a purely state-law dispute based on a contract for construction of a hospital addition. The hospital sued in state court, where, apparently concerned about an arbitration clause in the contract, it obtained an ex parte order enjoining Mercury from seeking enforcement of the arbitration clause-in effect enjoining Mercury from petitioning a federal district court to compel arbitration. The state court lifted the stay as soon as Mercury appeared in the action and objected, though the damage may well have been done in terms of offending the sensibilities of a federal judge sensitive to issues of civil rights. Mercury thereupon filed a diversity action in federal district court petitioning for a stay of the state-court case and an order compelling the hospital to arbitrate, pursuant to section 4 of the FAA. The district court, however, stayed the federal case in deference to the preexisting state case, and the appeal from the grant of the stay reached the Supreme Court. ${ }^{211}$

The principal issue presented to the Court was not in fact a dispute over the proper interpretation of the FAA, but rather an issue of federal abstention: whether, under the Colorado River doctrine ${ }^{212}$ it was proper for the federal court to stay the federal lawsuit in deference to the state-court case. The Court, per Justice Brennan, held that the district court erred by staying the federal action because doing so frustrated the policy implicit in the FAA's procedures favoring speedy resolution of the issue of enforceability of arbitration agree-

209. See, e.g., Warth v. Seldin, 422 U.S. 490 (1975) (using the standing doctrine to dismiss a challenge to alleged race discrimination in zoning); Younger v. Harris, 401 U.S. 37 (1971) (restricting federal courts' power to enjoin state-court proceedings). Specific examples of this type of civil rights dispute being encoded in procedural terms fill thousands of pages of treatises and casebooks on constitutional law and federal jurisdiction.

210. 460 U.S. 1 (1983).

211. Id. at 4-8.

212. See Colo. River Water Conserv. Dist. v. United States, 424 U.S. 800 (1976) (holding that the pendency of an action in state court is no bar to proceedings concerning the same matter in a federal court having jurisdiction). 
ments. That conclusion would have sufficed to resolve the case and would have been consistent with an understanding of the FAA as fundamentally procedural. But the Court went on. To buttress its conclusion that abstention was improper, the Court found it useful to add that "federal law provides the rule of decision on the merits" when stays pending arbitration are at issue, and specifically that the FAA governs the issue of arbitrability in either state or federal court:

Section 2 [of the FAA] is a congressional declaration of a liberal federal policy favoring arbitration agreements, notwithstanding any state substantive or procedural policies to the contrary. The effect of the section is to create a body of federal substantive law of arbitrability, applicable to any arbitration agreement within the coverage of the act. $^{213}$

Reading these sweeping statements, one cannot help but feel that the decision had very little to do with the actual FAA and very much to do with the judicial nationalist issues that were by 1983 receding quickly into the past. The notion that a federal court would stay litigation in deference to state court (let alone that a state court would try to enjoin a federal suit) would have been anathema to judges like Justice Brennan, whose judicial philosophy took shape in the era of official state obstruction of civil rights; Moses $H$. Cone might well have struck Justice Brennan and some of his colleagues as an opportunity to make good civil rights law in the coded form of neutral procedural and prudential rules.

At the same time, the Court's language about the federal pro-arbitration policy could have been lifted straight from Lincoln Mills and the Steelworkers Trilogy. ${ }^{214}$ Significantly, the analogy between federal labor policy and the FAA is faulty. Arbitration pursuant to collective bargaining agreements is a part of a substantive national labor policy. It is a quid pro quo for a union's giving up the right to strike, and therefore a "stabilizing" and "therapeutic" influence that promotes "industrial stabilization" and "industrial peace" nationwide. ${ }^{215}$ Arbi-

213. 460 U.S. at 24. In a footnote, the opinion recognizes that this reading of the FAA "creates something of an anomaly in the field of federal court jurisdiction" because the statute creates "a body of federal substantive law" without conferring "independent federal question jurisdiction." $I d$. at 25 n.32.

214. Compare Textile Workers Union v. Lincoln Mills, 353 U.S. 448, 450 (1957) (holding that section 201(a) of the LMRA "authorizes federal courts to fashion a body of federal law for the enforcement of these collective bargaining agreements"), and Steelworkers v. Am. Mfg. Co., 363 U.S. 564,567 (1960) (stating that judicial role is that "of developing a meaningful body of law to govern the interpretation and enforcement of collective bargaining agreements"), and Steelworkers v. Warrior \& Gulf Navigation Co., 363 U.S. 574, 577-78 (1960) (stating that the enforcement of arbitration agreements is "a major factor" in achieving "[t]he present federal policy . . . to promote industrial stabilization"), and id. at 582 ("[The] congressional policy in favor of settlement of disputes by the parties through the machinery of arbitration" requires that "doubts [about the scope of an arbitration clause] should be resolved in favor of coverage.”), and Steelworkers v. Enter. Wheel \& Car Corp., 363 U.S. 593 , 596 (1960) (holding that judicial review of arbitration awards must be limited to protect "[t]he federal policy of settling labor disputes by arbitration"), with Moses H. Cone, 460 U.S. at 24 ("[T]he effect of [FAA section 2] is to create a body of federal substantive law of arbitrability applicable to any arbitration agreement within the coverage of the act."), and id. ("[Q]uestions of arbitrability must be addressed with a healthy regard for the federal policy favoring arbitration.").

215. Am. Mfg. Co., 363 U.S. at 567-68; Warrior \& Gulf Navigation Co., 363 U.S. at 578. 
tration pursuant to the FAA is simply an alternative to litigation. The Supreme Court recognized the distinction at the time,${ }^{216}$ but seems to have forgotten the distinction in its discussions of the FAA during the 1980s.

\section{Assessing the "Intervening Developments"}

The "intervening developments" to which Justice Stevens referred as "compelling" Southland's basic conclusion that section 2 of the FAA preempts state law are undoubtedly those discussed above: the Moses H. Cone decision and the Bernhardt-Prima Paint handling of the FAA's perceived Erie problem. Yet, on closer analysis, these can hardly in themselves justify a decision that is wrong on the merits. What do these developments amount to? The Bernhardt-Prima Paint-Southland chain of reasoning is internally flawed and came into existence to solve the now nonexistent Erie problem of an outcome determinative FAA. The judicial nationalist history of the federal courts after the New Deal effected numerous changes from which there is doubtless no going back. But Southland's holding is not one of them. It is not a principle deeply embedded in our law, but rather an extension of some superficial reasoning from a recent-vintage case: Moses H. Cone's false analogy between the FAA on the one hand and federal labor arbitration and civil rights judicial nationalism on the other.

\section{VI}

\section{STARE DECISIS AND THE COURT'S OBLIGATION TO CORRECT ITS OWN FEDERALISM MISTAKES}

Although five Justices of the current Supreme Court have at some point dissented from Southland's basic conclusion, their opposition has never been unified in a single case. In Allied-Bruce Terminix Cos. v. Dobson, Justice O'Connor reluctantly abandoned her opposition to Southland: "Though wrong," Southland was by then supported by stare decisis, which the Court has said has "special force" in statutory interpretation cases. ${ }^{217}$ Absent "special justification' to overrule Southland," she felt compelled to "acquiesce" in the majority's admittedly faulty judgment. ${ }^{218}$ The three Southland dissenters remain on the Court, but none remains of the six Justices who formed the majority. It is conceivable that most or all the current Justices believe Southland is wrong but that a majority will continue to support it on stare decisis grounds alone. Like Justice Scalia, however, "I do not believe that proper application of stare decisis prevents correction of the mistake" of Southland. ${ }^{219}$

216. See Warrior \& Gulf Navigation Co., 363 U.S. at 578 (distinguishing labor arbitration from commercial arbitration).

217. 513 U.S. at 284 (O'Connor, J., concurring) (quoting Patterson v. McLean Credit Union, 491 U.S. 164, 172-73 (1989)).

218. Id. (quoting Arizona v. Rumsey, 467 U.S. 203, 212 (1984)).

219. Id. at 286 (Scalia, J., dissenting). 


\section{A. Statutory Stare Decisis Concerns}

Two concerns emerge from the relevant case law as salient justifications for the doctrine of giving special weight to stare decisis in statutory interpretation cases. ${ }^{220}$ One is a kind of congressional reliance interest. The courts often presume that Congress legislates with knowledge of background law, ${ }^{221}$ and there may be instances in which Congress builds on a foundation of Supreme Court statutory interpretations. ${ }^{222}$ But Congress may also build on nonstatutory case law, so this reliance argument does not justify giving special weight to statutory precedents. ${ }^{223}$ In any event, the congressional reliance interest is not very strong in the context of Southland because Congress has not amended the FAA in any way relevant to its preemptive effect since Southland. ${ }^{24}$

The other consideration weighing against overruling statutory interpretation precedents is the notion that "Congress remains free to alter what we have done." ${ }^{225}$ That argument is something of a makeweight. It applies equally to common law precedents, which benefit from no special rule of stare decisis, "and it is also a fairly lame argument. If the Court errs, why should the legislature have to make the correction?"226 It can also be argued that congressional acquiescence is a form of tacit approval of statutory precedents, but, again, the same could be said for common law precedents, and it is a stretch to attribute such definitive meaning to congressional inaction.

220. It is beyond the scope of this Article to engage in detail with the interesting scholarly debates over the justifications for statutory stare decisis. See, e.g., William N. Eskridge, Jr., Overruling Statutory Precedents, 76 GEO. L.J. 1361 (1988); Rafael Gely, Of Sinking and Escalating: A (Somewhat) New Look at Stare Decisis, 60 U. PITT. L. REV. 89 (1998). For an argument rejecting the conventional justifications for statutory stare decisis, but arguing that the doctrine is justified as a matter of democratic theory, see Lawrence C. Marshall, "Let Congress Do It": The Case for an Absolute Rule of Statutory Stare Decisis, 88 MiCH. L. REV. 177 (1989).

221. This is a dubious assumption. See Victoria F. Nourse \& Jane S. Schacter, The Politics of Legislative Drafting: A Congressional Case Study, 77 N.Y.U. L. REV. 575, 597-600 (2002) (using an empirical study to demonstrate, among other things, that legislative staffs often forego substantial legal research when drafting statutes).

222. See, e.g., Faragher v. City of Boca Raton, 524 U.S. 775, 792 (1998) (holding that stare decisis concerns are amplified by the likelihood that congressional amendments to the employment discrimination statute expanding employers' liability may have relied on earlier holdings about limits on employer liability).

223. See Eskridge, supra note 220, at 1401-02.

224. The only amendment to sections 1 through 4 of the FAA since the statute's enactment was the purely technical change of terminology in 1954 from "court of the United States" to "United States District Court" in section 4 to bring the provisions into conformity with present terms and practice. Act of Sept. 3, 1954, c. 1263, § 19, 68 Stat. 1233; see Southland Corp. v. Keating, 465 U.S. 1, 29 n.18 (1984) (O'Connor, J., dissenting). While the farfetched argument could be made that Congress, in creating new business for the federal courts, was counting on a quantum of federal cases being swept into arbitration, it is even more farfetched that Congress might have so relied on state-court dockets being cleared in that way.

225. Allied-Bruce Terminix Cos. v. Dobson, 513 U.S. 265, 284 (1995) (O'Connor, J., concurring).

226. Eskridge, supra note 220, at 1403. 
Leaving it to Congress in the case of Southland provokes a further objection: When, as here, the Court's statutory construction is flawed by a failure to give proper weight to federalism values, shrugging the problem off to Congress runs counter to the Court's recently espoused federalism principles. The decisions in United States v. Lopez $z^{227}$ and United States v. Morrison ${ }^{228}$ expressly rejected the theory that Congress, in whose political processes the states are represented, can by itself sufficiently protect federalism values and properly weigh them against perceived national legislative needs. ${ }^{229}$ To say that only Congress can correct federalism mistakes made by the Court in statutory interpretation is completely at odds with the Lopez-Morrison assertion of the judicial role in protecting federalism. There is no reason to believe that Congress will be more attentive to federalism concerns in reviewing judicial interpretations of its past enactments than it is in passing laws in the first instance. ${ }^{230}$

\section{B. "Special Justifications": Southland as a Latter-Day Swift v. Tyson}

The Court has not specified what "special justifications" support overruling a statutory precedent. Whatever they may be, an undeniable special justification exists for overruling Southland. In Allied-Bruce, the Court turned aside a request to overrule Southland, relying in part on the observation that "no subsequent cases have eroded Southland's authority." ${ }^{231}$ The Court thus overlooked Southland's inconsistency with recent Supreme Court decisions holding that arbitration enforcement is a matter of procedure with no impact on substantive rights. ${ }^{232}$ Indeed, with the exception of Moses H. Cone and Southland, the Court has been fairly consistent, dating all the way back to Justice Brandeis's opinion in Red Cross Line, in maintaining that the arbitration statutes are not substantive commerce regulation. ${ }^{233}$

227. 514 U.S. 549 (1995) (striking down the Gun Free School Zones Act).

228. 529 U.S. 598 (2000) (striking down the civil enforcement provision of the Violence Against Women Act).

229. The theory that federalism is adequately protected by "political safeguards," and therefore requires no more than very deferential judicial review, was articulated by a five-Justice majority in Garcia v. San Antonio Metropolitan Transit Authority, 469 U.S. 528, 550-52 (1985), and reasserted by the dissenters in Morrison, 529 U.S. at 647-52 (espousing "[t]he Garcia Court's rejection of 'judicially created limitations' in favor of the intended reliance on national politics"). The Morrison majority rejected this theory in overruling Garcia: "No doubt the political branches have a role in interpreting and applying the Constitution, but ever since Marbury this Court has remained the ultimate expositor of the constitutional text." Morrison, 529 U.S. at 617 n.7. The majority found the "political safeguards" theory to be "remarkable because it undermines this central principle of our constitutional system." Id.

230. Reliance by private parties is, of course, another rationale for stare decisis in general, but it does not supply a reason for a special, strong rule of stare decisis in statutory interpretation cases. In the case of Southland, the argument based on reliance by private parties is further weakened by the Supreme Court's contention that arbitration does not affect substantive rights. See Allied-Bruce, 513 U.S. at 284-85 (Scalia, J., dissenting).

231. Id. at 272.

232. See supra text accompanying notes $192-96$.

233. See supra text accompanying notes 116-19, 156-62, 187. Again, Bernhardt held that the FAA was substantive only insofar as a procedural rule can be deemed "outcome determinative" for the pur- 
Justice Brandeis wrote in dissent from another statutory interpretation decision that stare decisis "is not an inexorable command. The instances in which the court has disregarded its admonition are many." ${ }^{234}$ Fourteen years later, a majority of the Court would join Brandeis in the twentieth century's most famous example of the Court overruling a statutory precedent. Because the holding is known as overruling the doctrine of general federal common law, it is easy to overlook the fact that Erie, in overruling Swift, reversed Swift's interpretation of section 34 of the Judiciary Act of 1789-an interpretation that had stood for ninety-six years.

The comparison to Erie here is more to the point than one might suppose. A special justification to overrule a statutory precedent might well be present when, on reconsideration, a constitutional question is raised by the Court's prior interpretation. That was the rationale in Erie, in which the Court concluded that the judicial interpretation given to section 34 by Swift-not the statute itself-was unconstitutional because it allowed the federal courts to make law on subjects outside the legislative power of Congress. Southland held that a state statute "violate[d] the Supremacy Clause" and was void because it conflicted with section 2 of the FAA. This displacement of state law-a judicial act that is itself of constitutional significance ${ }^{235}$-was based on an erroneous interpretation of the FAA as substantive rather than procedural law.

Southland took up the invitation in Moses H. Cone to view the FAA as an authorization for federal courts to create "a body of federal substantive law" along the lines of the federal common law of labor arbitration pursuant to the LMRA. ${ }^{236}$ If the FAA was intended to be-or is now fundamentallyprocedural law, its use as a basis for the creation of federal law that preempts state lawmaking is constitutionally problematic under Erie. Any Justice who sees the FAA in that light would have a "special justification" to overrule Southland, a justification that is in one important sense stronger than the one in

poses of Erie. Prima Paint held that procedural but outcome determinative rules could be enacted under the commerce power without offending Erie.

234. Washington v. W.C. Dawson \& Co., 264 U.S. 219, 238 (1924) (Brandeis, J., dissenting). "Notwithstanding the rule [of statutory stare decisis], the Supreme Court ... overruled or materially modified statutory precedents more than eighty times" between 1961 and 1988. Eskridge, supra note 220, at $1363,1427-39$. One need not look beyond the FAA to find examples of the Court overruling statutory interpretation precedents. See Rodriguez de Quijas v. Shearson/Am. Express, 490 U.S. 477, 481 (1989), overruling Wilko v. Swan, 346 U.S. 427 (1953). In addition, the Court has overruled two statutory interpretation doctrines that had gained unanimous or near-unanimous agreement among the courts of appeals. See Mitsubishi Motors Corp. v. Soler Chrysler-Plymouth, Inc., 473 U.S. 614, 655-56 (1985) (Stevens, J., dissenting) (pointing out that the majority opinion overruled the unanimous view of the courts of appeals that antitrust claims are not arbitrable); Schwartz, supra note 52, at 93-94, 103-04 (noting that Gilmer v. Interstate/Johnson Lane Co., 500 U.S. 20 (1991), overruled the near-unanimous view of the lower courts that employment discrimination claims are not arbitrable).

235. It is commonplace to relegate preemption decisions to the realm of statutory interpretation, but there is an undeniable constitutional dimension to a court's holding that a state statute is void on preemption grounds. In that sense, the Southland majority was quite right to couch its holding in the constitutional terms of the Supremacy Clause.

236. Moses H. Cone Mem'l Hosp. v. Mercury Constr. Corp., 460 U.S. 1, 24 (1983). 
Erie. Although arbitration is narrower in scope than the general federal law considered in Erie, its effect on the states goes deeper: federal common law under Swift was not applicable in state courts, and technically (if not always perfectly in practice), state statutes could in effect overrule federal common law decisions. But the federal common law of the FAA binds state courts and nullifies state statutes.

A Supreme Court truly interested in federalism should, like the Court in Erie, look very carefully at any sweeping claims that an act of Congress has broadly authorized the courts to create a body of federal common law. Here, Moses H. Cone found such authority in the FAA by analogy to the lawmaking authority over labor arbitration the federal courts have derived from section 301 of the LMRA. ${ }^{237}$ But that analogy is unsound. Unlike arbitration agreements governed by federal labor law, private contractual arbitration agreements were not seen by the Congress that passed the FAA as being of special federal concern; that is to say, Congress evinced a concern only to bring such agreements into general contract law, not to lift them out of it and into a special, protected category. ${ }^{238}$ Collective bargaining agreements, on the other hand, although private contracts in form, have long been regarded as contracts carrying national public-policy implications due to the history of labor strife. ${ }^{239}$ Nationwide unions and the major impact of labor relations on interstate commerce were specifically noted in the legislative histories and the provisions of both the LMRA and the National Labor Relations Act (NLRA) ${ }^{240}$ Such congressional expressions of national policy imply a need for uniformity that may well justify the making of federal common law, but these seem wholly absent from the FAA.

In this light, Southland's interpretation of the FAA is constitutionally dubious. Congress's power to dictate state procedures for the resolution of federal claims is limited and subject to some doubt. ${ }^{241}$ The FAA, under Southland,

237. See supra text accompanying note 214.

238. The FAA "places such agreements to arbitrate on the same footing as other contracts." H.R. REP. No. 68-96, at 1 (1924); accord Prima Paint Corp. v. Flood \& Conklin Mfg. Co., 388 U.S. 395 , 404 n.12 (1967) ("[T]he purpose of Congress in 1925 was to make arbitration agreements as enforceable as other contracts, but not more so.").

239. See supra notes 203-04, 214-15 and accompanying text.

240. See National Labor Relations Act, 29 U.S.C. $\S \S 141-44,151-58,159-67,171-83,185-87,557$ (2000); Labor Management Relations Act, 29 U.S.C. § 151 (2000); 93 CONG. REC. 6600 (1947) (statement of Sen. Taft); 93 CONG. REC. 3656-57 (1947).

241. In the absence of a state rule that uniquely burdens a federal "right of recovery" by imposing particular procedural obstacles, it is doubtful whether any federal power exists at all to control neutral state procedures in federal question cases. See Johnson v. Fankell, 520 U.S. 911, 919 (1997) (holding that a neutral state rule denying interlocutory appeals was not preempted by a federal rule allowing such appeals for $\S 1983$ defendants); Howlett v. Rose, 496 U.S. 356, 372 (1990) ("[F]ederal law [normally] takes the state courts as it finds them."); see also Wendy E. Parmet, Stealth Preemption: The Proposed Federalization of State Court Procedures, 44 VILL. L. REV. 1, 42-52 (1999) (canvassing federalism problems in federal regulation of state court procedures). Since this Article was substantially completed, I have come to the conclusion and argued elsewhere that Southland's rule of FAA preemp- 
amounts to a restructuring of state judicial processes on the procedural question of forum selection, even for purely state-law claims. Where state-court cases are concerned, the choice is between litigating before judges in a state-court system or before an arbitrator in a conference room in a private office suite. In other areas in which Congress has displaced state adjudicative processes through statutes either granting federal courts exclusive jurisdiction, such as the Securities Exchange Act, ${ }^{242}$ or creating national tribunals, such as the NLRA, ${ }^{243}$ the displacement is (or should be) justified by a set of substantive policies deemed suitable for uniform, national treatment. ${ }^{244}$ Even if one were tempted to argue that the FAA creates a substantive rule of contract interpretationthat arbitration agreements will always be enforced despite contrary state policies-no substantive subject matter underlies the law, which deals only with the forum choice. The notion that a strong, substantive federal interest must be present to justify the preemption of state law is a corollary of the doctrine of enumerated powers. That a statute dealing fundamentally with procedure would preempt state law, or that an act of Congress would regulate state courts on a matter of procedure under the Commerce Clause seems constitutionally problematic. $^{245}$

To be sure, overcrowded state-court dockets may well spill over onto federal dockets, and it would be easy for Congress to make a case that state disputeresolution systems "affect interstate commerce." Perhaps-though it seems doubtful-Congress has the power to dictate at least some terms about how states must structure their judicial or dispute-resolution systems. Yet, were Congress to make such a major intrusion into state autonomy based on so very weak a federal interest, this would at minimum raise a serious constitutional

tion is unconstitutional. See David S. Schwartz, The Federal Arbitration Act and the Power of Congress over State Courts, 83 OR. L. REV. (forthcoming 2004).

242. 15 U.S.C. $\$ 78 \mathrm{aa}(2000)$.

243. 29 U.S.C. $\$ 160$ (2000) (creating the National Labor Relations Board).

244. See Matsushita Elec. Indus. Co. v. Epstein, 516 U.S. 367, 383 (1996) ("We may presume, however, that Congress intended $\S 27$ to serve at least the general purposes underlying most grants of exclusive jurisdiction: to achieve greater uniformity of construction and more effective and expert application of that law.") (quotations omitted); San Diego Bldg. Trades Council v. Garmon, 359 U.S. 236, 241-42 (1959) (describing the overriding need for uniform national labor policy to justify the preemptive primary jurisdiction of the National Labor Relations Board).

245. Is it supportable for the Court to use the FAA as a point of departure for a "national judicial policy favoring arbitration"? Might it not be said that federal courts, as a matter of separation of powers, should be allowed to fire a shot across the bow of a Congress that it may feel is creating too much work for the federal courts (in the form of new causes of action) while being laggard in filling judicial vacancies? Cf. Neal Devins, Congress as Culprit: How Lawmakers Spurred on the Court's AntiCongress Crusade, 51 DUKE L.J. 435, 454-58 (2001) (arguing that this separation-of-powers motive explains much of the "new federalism"). Wholly apart from Southland's premise that the FAA reflects a congressional pro-arbitration policy enacted pursuant to the Commerce Clause (and not Article III), the federal judicial interest in imposing a procedural policy on the states does not seem any stronger than the congressional interest. The impact of state-court dockets on federal dockets is indirect. It is one thing for federal courts to bar their own courthouse doors to litigants, but quite another to bar the doors of state courts. In any event, Gregory and the federalism revival suggest that the Court is to be a guardian of federalism rather than a source of anti-federalism policy. 
question. The Court should apply a heavy presumption against giving the FAA such an interpretation. ${ }^{246}$ Thus, even if Southland is not unconstitutional, its interpretation of the FAA raises serious, unaddressed constitutional doubts. Southland should be overruled.

\section{VII}

\section{RECONSTRUCTING THE FAA}

If Southland were overruled, what doctrine would replace it? Three plausible interpretations of the FAA emerge from the historical record and the various dissents.

\section{A. Stevens's Southland Dissent}

Justice Stevens argued in Southland that the FAA leaves room for the states to create specific public policy exceptions to what he sees as the FAA's otherwise general rule of arbitration enforcement. Essentially, this interpretation accepts the Southland majority's position that the FAA is substantive law binding on the states, but gives a broader reading to the savings clause than did the majority. Rather than being limited to generic state-law contract defenses, the section 2 savings clause's reference to "grounds that exist at law or in equity for the revocation of any contract" would include the ground that contracts against public policy are void. "I believe that [the savings clause] leaves room for the implementation of certain substantive state policies that would be undermined by enforcing certain categories of arbitration clauses."247 Under this view, a state could determine that a judicial forum should be preserved for certain types of claims, though a state law invalidating arbitration agreements across the board would be preempted.

This interpretation shares the flaw of the majority opinion by assuming that the FAA creates a substantive right enforceable in state court. It does, however, have the virtue of offering a plausible interpretation of the savings clause that attempts to take state sovereignty into account and to reduce the FAA's preemptive scope. Moreover, the Stevens approach suggests that a state law barring predispute arbitration agreements in certain contexts-such as the provision of the California Labor Code considered in Southland-is also substan-

246. See Gregory v. Ashcroft, 501 U.S. 452, 460 (1991); supra text accompanying notes 49-51. The long-established principle of constitutional avoidance also supports construing the FAA to avoid constitutionally dubious preemption of state law. "If a case can be decided on either of two grounds, one involving a constitutional question, the other a question of statutory construction of general law, the Court will decide only the latter." Ashwander v. Tenn. Valley Auth., 297 U.S. 288, 347 (1936) (Brandeis, J., concurring). Thus, "where an otherwise acceptable construction of a statute would raise serious constitutional problems, the Court will construe the statute to avoid such problems unless such construction is plainly contrary to the intent of Congress." Solid Waste Agency v. Army Corps of Eng'rs, 531 U.S. 159, 173 (2001). The Court has failed to apply this principle in the Southland line of cases.

247. Southland Corp. v. Keating, 465 U.S. 1, 18 (Stevens, J., dissenting). 
tive, and therefore, under Erie, should be enforceable even in federal court, in diversity and ancillary jurisdiction cases. ${ }^{248}$

\section{B. The O'Connor-Scalia-Thomas Position}

Justice O'Connor in Southland and Justices Scalia and Thomas in AlliedBruce argued that the FAA is a rule of procedure applicable only in federal court. ${ }^{249}$ This interpretation gives due regard to federalism concerns and is true to the original intent of the FAA. It also is consistent with the language of the statute and with the Court's decisions holding arbitration enforcement to be a procedural right that is not outcome determinative. Finally, it would reconcile the arbitration-enforcement right with the statute's clearly implied withholding of subject matter jurisdiction. Adopting the O'Connor-Scalia-Thomas position would entail overruling Southland as well as the language in Moses H. Cone asserting that the FAA creates substantive federal law.

This "procedural FAA" approach need not give rise to an Erie problem. In the absence of Southland, the FAA's applicability in federal diversity cases would be sanctioned by Prima Paint's holding that federal court procedure may be governed by any statute within the power of Congress without triggering the Erie analysis outlined in Hanna v. Plumer. Ironically, this approach might leave less of an entree for state law in federal court, via the savings clause, than the Stevens approach. If the enforcement of arbitration agreements were deemed a question of procedure, even one that is outcome determinative, then there would be an argument that state policies restricting arbitration in certain classes of cases-those that Justice Stevens would import via the savings clause-are procedural and therefore would not apply in federal court.

\section{The Savings Clause Interpretation}

The substance/procedure distinction is not, of course, an end in itself, but a way of analyzing and deciding the extent of the FAA's application. Conceivably, the drafters of the Act and the Congress that passed it concerned themselves with the substance/procedure distinction only as a means to an end-to navigate doctrinal objections that might be given credence in the courts. Especially in light of the double-turnaround of $1938,{ }^{250}$ the intent of Congress that the FAA be deemed substantive or procedural should matter less than the answer one reaches to two fundamental questions: First, does the FAA preempt state law? Second, if not, what room does it leave for state law in the federal courts?

248. Id. at 19-20 (Stevens, J., dissenting).

249. See Allied-Bruce Terminix Cos. v. Dobson, 513 U.S. 265, 284-85 (1995) (Scalia, J., dissenting); $i d$. at 285-96 (Thomas, J., dissenting); Southland, 465 U.S. at 21-36 (O'Connor, J., dissenting).

250. The Federal Rules of Civil Procedure went into effect in 1938, the same year as the Erie decision. "To oversimplify the transformation: Before 1938 the federal courts in diversity cases applied federal substantive law through state procedure (except in equity cases); after 1938 they applied state substantive law through federal procedure." JAMES FLEMING \& GEOFFrEY HAZARD, CiviL PROCEDURE $§ 2.35$, at 119 (3d ed. 1985). 
The answer to the first question is clear: Congress had no intention when it enacted the FAA in 1925 to preempt any state law, not even a state statute like Alabama's, which refused enforcement of all predispute arbitration agreements. Any policies and case law developments that have arisen since 1925 are sufficiently counterbalanced by the federalism concerns espoused by the Court over the past decade to justify a refusal to depart from Congress's original intent on this point.

The answer to the second question leaves more room for disagreement. Clearly, the savings clause preserves substantive law relating to the validity and revocability of contracts. In 1925, this would have meant federal decisional law and state statutes under the Swift regime; since Erie, it should mean state decisional law and state statutes. The more difficult question is what else the savings clause covers. The Supreme Court has construed it to refer only to "generally applicable" contract law. ${ }^{251}$ But this interpretation is unduly narrow. First, it gives rise to an ongoing ambiguity. "General contract law" doctrines, such as unconscionability, are only meaningful when applied to specific situations: an arbitration agreement may be unconscionable even though other terms of the same contract are not. Second, as the Stevens interpretation points out, the "general contract law" interpretation prevents the application of state policies preserving a judicial forum for certain categories of cases.

Even Justice Stevens's view is too narrow. According to Justice Stevens, a state policy expressing "general hostility" to arbitration conflicts with the FAA. But the FAA was enacted to overrule the ouster doctrine and decisional law declining specific enforcement and stays of litigation. The "old judicial hostility" to arbitration agreements was based on judicial assertions of the power of courts-that it was against public policy to enforce private agreements depriving or "ousting" courts of jurisdiction. The ouster doctrine was not based on substantive contract law relating to contract formation and defenses, but was rather a judicial policy governing jurisdiction and judicial administration. An anti-arbitration policy based on contract law is different. For example, a state legislature or court might determine that given the nature of the rights waived and the disparity between the parties in information and bargaining power, predispute arbitration agreements are always unconscionable as a matter of law. As long as an arbitration-specific regulation is based on such concerns, which are general contract-law concerns applied to the specific case of arbitration agreements, rather than on the judicial power concerns underlying the ouster doctrine, the state rule should be deemed saved within the savings clause. Such state-law doctrines should not only be saved from preemption in state-court cases but should also be applied (at least to state-law claims) in federal court via the savings clause.

This broad reading of the savings clause finds support in two further respects. First, it is consistent with the existing doctrine that general contract-

251. Doctor's Assocs. v. Casarotto, 517 U.S. 681, 687 (1996). 
law defenses are applicable to invalidate an arbitration agreement. After all, such doctrines as unconscionability, duress, mistake, and the like must be applied to a specific case involving an arbitration agreement. There is no reason that a court should be allowed to apply general contract-law principles to an arbitration agreement in a specific case while a legislature or court is forbidden from doing so in a class of cases. The distinction is hard to justify. Second, this broad reading of the savings clause is consistent with a federalism-based statutory interpretation. Although "Congress may legislate in areas traditionally regulated by the States" when it acts within its enumerated powers, "Congress does not exercise [this power] lightly."252

\section{The End of Arbitration?}

Overruling Southland would correct a mistake of statutory interpretation and eliminate the intense contradiction between FAA preemption of state law and the federalism principles espoused by the Supreme Court over the past decade. It would not spell the end of arbitration-not even compelled predispute arbitration. Most states have arbitration statutes and judicially created pro-arbitration policies similar to those under federal law. State statutes preserving a judicial forum exist only in a minority of states for a minority of claims. At the same time, the presumption that statutory claims are arbitrable would not be implicated by overruling Southland. ${ }^{253}$ Some might argue that overruling Southland's imposition of a uniform, national rule would produce judicial inefficiencies. Such blanket efficiency arguments are always present when states exercise regulatory autonomy in our fifty-state federal system, and they almost never take seriously the cost of such "efficiency" on federalism values. To be sure, overruling Southland, and thus reviving the various state laws precluding arbitration for certain types of claims, would create some procedural complexities in the form of more cases involving both arbitrable and nonarbitrable claims, though some exist even under current law. In federal court, two factors might limit the potential for increased procedural maneuvering. First, FAA doctrine provides that arbitrable claims must be arbitrated before nonarbitrable claims are adjudicated. ${ }^{254}$ Second, because overruling Southland would on the whole revive state courts as a forum for claims, there might be a reduction of federal filings. Plaintiffs in many instances might pursue state-law claims and forego federal claims to avoid removal to a federal forum, where arbitration would be compelled. If the increased judicial business created a problem for states, that could be handled by the appropriate state legislatures. That is, after all, how the federal system is supposed to work.

252. Gregory v. Ashcroft, 501 U.S. 452, 460 (1991).

253. See Gilmer v. Interstate/Johnson Lane Corp., 500 U.S. 20, 31-34 (1991) (citing cases); Schwartz, supra note 52, at 95-104 (summarizing the case law holding statutory claims arbitrable).

254. See Dean Witter Reynolds, Inc. v. Byrd, 470 U.S. 213, 220-21 (1985). 


\section{VIII}

\section{CONCLUSION}

Southland and its progeny are the result of bad statutory interpretation and even worse federalism. The historical evidence demonstrates that Congress never intended to preempt state law regulating arbitration agreements. To the contrary, the best interpretation of the FAA is that, by virtue of its savings clause, federal courts should normally be bound by state-law restrictions on arbitration enforcement. The evidence against Southland is so strong that it seems that no one defends it on the merits anymore: Southland lives on only because of the Court's reluctance to overrule a statutory interpretation precedent, its desire to spread arbitration far and wide, or a combination of the two. Neither justifies continuing the regime of Southland's preemption of state law.

In Southland, the Court made an error of constitutional proportions that is in significant respects comparable to the error of Swift v. Tyson, which the Court famously corrected in Erie. The Southland decision itself was the outgrowth of a series of misapplications of the Erie doctrine to the FAA combined with the vestiges of a judicial nationalism that mistakenly tethered the FAA to federal labor policy and that was already on the decline when Southland was decided. The doctrine created by Southland intrudes heavily on state sovereignty by preempting numerous state efforts to regulate abuses associated with arbitration agreements. At the same time, Southland authorizes the creation of a body of federal common law that, while not as broad in subject matter as that created by the federal courts under Swift, cuts deeper into state sovereignty because of its preemptive effect. And whatever one's views on the desirability of arbitration as a form of alternative dispute resolution, the FAA's preemptive effect under Southland is unsupported by any significant federal interest. In sharp contrast with the federal common law of arbitration in the labor settingbased on a perceived need for national uniformity to promote industrial peace between nationwide unions and employers-Congress has no particular interest in directing the intrastate forum choice between arbitration and a state court.

Stare decisis notwithstanding, the court should not leave it to Congress to correct the mistake of Southland. If the Court is credibly to claim a significant role for itself in safeguarding the federal system from overreaching by Congress, the Court should not abdicate its federalism-enforcing role when the mistake is of its own making. 